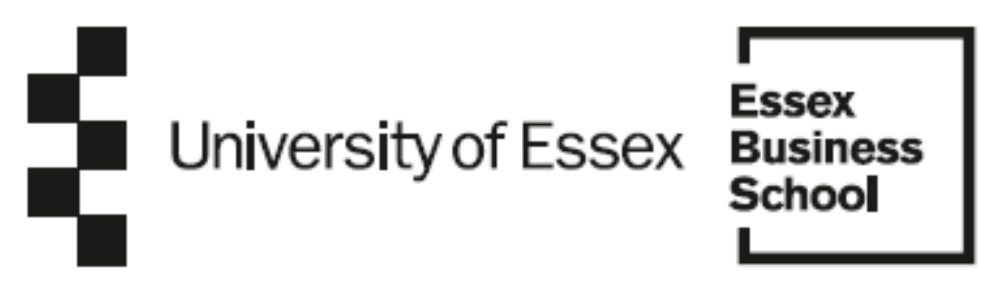

\author{
Essex Finance Centre \\ Working Paper Series
}

"The Rise of Regional Financial Cycle and Domestic Credit Markets in Asia"

"Chiara Banti, Udichibarna Bose" 


\title{
The Rise of Regional Financial Cycle and Domestic Credit Markets in Asia
}

\author{
Chiara Banti ${ }^{*}$, Udichibarna Bose \\ Essex Business School, University of Essex, Colchester CO4 3SQ, UK
}

\begin{abstract}
This paper documents the emergence of a regional financial cycle in Asia, evidenced by commonality in regional bank flows, and its impact on domestic credit. Using a dataset of 24,169 non-financial Indian firms for the period 2001-2019, we establish that the regional financial cycle has a positive and significant impact on domestic corporate debt, as opposed to an insignificant effect on foreign currency corporate debt, after controlling for the global financial cycle. We find that both interbank markets and monetary policy conditions in the region act as transmission channels for this effect. We show that transparent firms which have lower monitoring costs are relatively more exposed to the regional financial cycle, suggesting that affiliates of foreign banks play an important role. However, the exposure of domestic credit markets reduces once regulators institute more stringent policy actions such as macroprudential policies, selective capital controls and floating currency regimes.
\end{abstract}

JEL Classification codes: E44; F34; F40; G15; G30

Keywords: Regional financial cycle; domestic credit markets; macroprudential policies; capital controls; emerging markets

* Corresponding author: Email: cbanti@essex.ac.uk. We are thankful to Jerry Coakley, Claudia Girardone, Sotirios Kokas and the participants at the Essex Finance Centre seminar (2021) for all their insightful comments. Any remaining errors are our own. 


\section{Introduction}

Since the seminal work by Rey (2013), commonality in global financial conditions (also referred as the global financial cycle) has received considerable attention along with the special focus on US monetary policy in shaping it. ${ }^{1}$ The relevance of the global financial cycle differs across advanced economies and emerging markets (EMs) with a higher exposure of bank flows for advanced economies (Cerutti, Claessens and Rose, 2019; Aldasoro et al., 2020), while idiosyncratic factors are likely to drive bank flows in EMs. Consistently, there is evidence of commonality in financing conditions within EMs (Aldasoro et al., 2020) and within regions around the world (Adarov, 2020). Substantial transformations have characterized global credit dynamics over the last few decades, with the retrenchment of global banks, especially European ones, and the emergence of regional as well as emerging market lenders (Cerutti and Zhou, 2017; Cerutti, Koch and Pradhan, 2018; Bénétrix et al., 2019). Nonetheless, the emergence of regional financial cycles and their impact on domestic credit have been largely overlooked in the literature. We fill this gap in the literature and address this issue by focusing on Asia as there is compelling evidence of emergence of significant regional lenders. Indeed, banks from Japan and China have become the important drivers of regional lending in Asia (International Monetary Fund, 2015; Koch and Remolona, 2018). In this paper, we investigate whether these developments have led to the emergence of a regional financial cycle in Asia by focusing on the firm-level evidence from India. Differently from previous studies on financial cycles that focus on the exposure of bank flows, to the best of our knowledge, this is the first paper studying the impact of regional financial cycle on domestic credit markets.

Employing a detailed firm-level dataset of 24,169 non-financial Indian firms for the period 2001-2019, we analyze whether domestic credit markets are affected by the regional financial cycle, after controlling for the global financial cycle. India provides a representative case for the analysis of regional lending in Asia for two main reasons. First, there are several similarities in the structure of the Indian economy with other economies in the region - such as the degree of underdevelopment of corporate bond and foreign exchange (FX) hedging markets, the presence of domestic credit market frictions and the dual structure of formal-informal finance (Allen et al., 2012; Banerjee and Mohanty, 2021). Cross-border bank flows to the countries in the region exhibit

\footnotetext{
${ }^{1}$ The literature on capital flows and global factors is vast starting from the work on push and pull factors by Calvo, Leiderman and Reinhart $(1993,1996)$. See Koepke (2019) for a recent review of the literature.
} 
significant commonality, as documented by the cross-country correlation analysis provided in Table 1. Second, India is one of the largest and fastest growing economies in the world, ${ }^{2}$ with important global and regional economic linkages. Its interconnection to global markets was reflected by the particularly large capital outflows and currency depreciation during the 2013 taper tantrum episode (Azis and Shin, 2015; Banti and Bose, 2021). As such, India provides a comprehensive case to study rising FX risk exposures especially in the aftermath of Global Financial Crisis (GFC), and cross-border monetary transmissions via regional and global financial channels for other economies in the region. Furthermore, this study is also relevant for other EMs as several studies have documented the risks related to global factors and foreign debt issuances for emerging market corporate borrowers (Chung et al., 2015; McCauley, McGuire and Sushko, 2015; Alter and Elekdag, 2020; Bräuning and Ivashina, 2020). However, in our paper, we compare and contrast the role of regional and global financial cycles on domestic and foreign corporate borrowings as we believe that differentiating between domestic and foreign borrowings is crucial to disentangle the exposure of credit markets to external factors. Indeed, we find that the regional financial cycle only influences domestic corporate debt, whereas foreign corporate debt is only affected by the global financial cycle. These findings indicate the presence of different channels through which external factors related to the regional and global financial cycles operate. The identification of these channels is essential to devise appropriate and effective policy frameworks to manage countries' exposure to these factors.

Interbank markets are likely to play a key role in the exposure of domestic credit markets to both global and regional factors. ${ }^{3}$ Focusing on global credit shocks, Cetorelli and Goldberg (2011) identify interbank markets as the main source of transmission of global shocks to EMs during the GFC, which is also confirmed by Avdjiev, McGuire and von Peter (2020). Focusing on the drivers of bank deleveraging during the GFC, Cerutti and Claessens (2017) document significant differences between international lending via affiliates and direct cross-border bank lending. The literature proposes two main channels for the transmission of monetary policy across borders through bank lending, focusing specifically on the role of US monetary policy. Although these channels are generally related to global banks, our main empirical findings suggest that

\footnotetext{
${ }^{2}$ India is the sixth largest economy in the world by GDP (current US dollars in 2020, World Bank).

${ }^{3}$ Although bond issuances have become more important in the post-GFC period, Asian firms mostly rely on bank loans as opposed to bond financing for their external financing (Duffee and Hördahl, 2021).
} 
regional banks are equally important and able in transmitting these effects. ${ }^{4}$ On one hand, the "bank lending" channel emphasizes the role of leverage in global banks such that a US monetary policy contraction leads to global bank deleveraging and reducing the global supply of credit (MirandaAgrippino and Rey, 2020). Bruno and Shin (2015) present a related "risk-taking" channel of currency appreciation. They show that a strong dollar, together with the corresponding depreciation of the domestic currency, worsen the balance sheet of domestic borrowers and their credit risk profile, in turn constraining banks' lending capacity and credit provision. ${ }^{5}$ On the other hand, the "international portfolio rebalancing" channel focuses on the relocation towards safer borrowers abroad triggered by the decline in net worth and collateral value of US domestic borrowers following a monetary policy tightening in the US (Correa et al., 2021). Moreover, as higher interest rates in the US reflect benign economic conditions in advanced economies, they may result in higher confidence of international lenders and a "search for yield" behavior that increases credit supply globally. Avdjiev and Hale (2019) establish that the channel which dominates the dynamics of bank flows is determined by the risk tolerance regime. Moreover, Buch et al. (2019) show that different countries exhibit different channels at work at the same time.

Aside from bank lending, external factors can also affect corporate borrowings via the domestic monetary policy responses. To reduce pressure on the exchange rate, central banks may alter domestic interest rates and cost of financing for corporations, in turn. This may lead to increasing bond issuances by corporations domestically or abroad. In this respect, easing financing conditions in global markets, may trigger portfolio rebalancing by asset managers in search for yields towards high-yield issuances by emerging market corporations (Avdjiev, Chui and Shin, 2014; McCauley, McGuire and Sushko, 2015; Caballero, Panizza and Powell, 2016; Lo Duca, Nicoletti and Vidal Martínez, 2016). Further, as Asia is characterized by strong regional economic integration and strong trade linkages (Hirata, Kose and Otrok, 2013), the economic performance of the major countries in the region may also influence corporate borrowings via the demand for exports.

\footnotetext{
${ }^{4}$ In this paper, we refer to regional banks as the banks that are headquartered in the geographical Asian region (Cerutti and Zhou, 2017)

${ }^{5}$ Banerjee and Mohanty (2021) empirically document this effect for Indian firms, while Avdjiev and Takáts (2019) study the role of currency networks in international transmission of monetary policy spillovers.
} 
This paper adds three main contributions to the existing literature. First, we document the existence of a regional financial cycle in Asia that is relevant for domestic credit markets and is driven by funding conditions in interbank markets and monetary policy in regional lender countries. Although the literature has generally documented limited regional financial integration contrasted with strong global linkages (Eichengreen and Park, 2005; Kim, Lee and Shin, 2008; Park and Shin, 2009), the emergence of a regional financial cycle reveals growing financial integration in Asia (Bouvatier and Delatte, 2015). ${ }^{6}$

The literature on capital flows has focused mainly on global dynamics, the global financial cycle and global liquidity, and generally documented a significant impact of global factors on firms' foreign borrowings and leverage (Chung et al., 2015; McCauley, McGuire and Sushko, 2015; Arregui et al., 2018; Alter and Elekdag, 2020; Bräuning and Ivashina, 2020), but the regional dynamics have received far less attention. We contribute to this literature by identifying different transmission channels for regional and global factors. Our main finding of the relevance of regional financial cycle for domestic corporate debt exclusively indicates that the exposure to the regional financial cycle may originate from lending activity of affiliates of regional banks and/or domestic banks that obtain wholesale funding regionally. In addition, our finding of the global financial cycle affecting corporate FX borrowings indicates that this effect is likely to be transmitted via the lending activity and portfolio allocations of global banks and global investors. These results have important policy implications. The exposure to the regional financial cycle provides diversification to countries' reliance on global banks in favor of regional and domestic actors. From a financial stability perspective, this growing exposure may contain countries' exposure to global factors mainly originating in the US. Given the currency component, FX risk is not likely to arise from the exposure to regional factors. Among the drivers of the global financial cycle, only uncertainty in the US monetary policy affects both domestic and foreign corporate debt strongly. This is indeed consistent with the dramatic impact of the 2013 taper tantrum episode on EMs when capital inflows stopped suddenly, but it also points towards a potential wider impact beyond FX (mainly USD)

\footnotetext{
${ }^{6}$ Countries in the region have adopted various initiatives to foster regional financial integration including the Chiang Mai multilateral currency swap initiative and the Asian Bond Markets Initiative (ABMI). Importantly, regional multilateral cooperation extends to knowledge and information exchange about capital flows within the SEACEN centre that is a regional research and learning hub for central banks in the Asia-Pacific region.
} 
denominated debt to domestic debt. ${ }^{7}$ Moreover, we show that when regional monetary policy diverges from monetary policy in the US, the impact of the regional financial cycle grows stronger.

The literature has also documented the growing importance of Japanese and Chinese banks as key lenders in the region after the GFC (International Monetary Fund, 2015; Koch and Remolona, 2018). Turning to the sources of cross-border bank credit, we show that Japanese financing conditions play a leading role in the dynamics of the regional financial cycle, while the relevance of Chinese factors is still relatively limited but emerging. Importantly, as opposed to the global financial cycle that is US-centric, the regional financial cycle appears to stem from financing conditions in a group of key lenders. Although Japanese factors exert the strongest impact, financial conditions in other lender countries, such as Australia and Singapore, have a significant impact on domestic credit too.

Our second contribution relates to the literature investigating whether domestic and international financial markets are substitutes or complements and argues that financial frictions can lead to market segmentation, preventing some firms and investors to participate in international financial markets. For instance, information asymmetries, transaction costs, and regulation can inhibit some firms from using certain markets and/or result in certain investors and financial intermediaries dominating specific markets (Bekaert et al., 2011; Abraham, Cortina and Schmukler, 2021). Thus, even in an increasingly globalized world in which financial transactions can take place anywhere, domestic intermediaries still play a meaningful role for emerging economy firms. The literature on the role of foreign banks in domestic credit markets documents that foreign banks tend to lend more to local borrowers that require less soft information due to relatively stronger information asymmetries (Mian, 2006; Berger et al., 2008; Gormley, 2010). This also has implications on the transmission of monetary policy. Focusing on firm and banklevel data for Mexico, Morais et al., (2019) document that foreign monetary policy affects lending via the respective foreign banks, that is, US, EU, and UK banks transmit US, EU and UK monetary policy shocks, respectively. Our results show that transparent firms with lower monitoring costs are more exposed to the regional financial cycle in the domestic credit markets. Building on the

\footnotetext{
${ }^{7}$ In May 2013, Bernanke's speech on future tapering of the US quantitative easing policy triggered episodes of capital inflow reversals (Bank for International Settlements, 2013). This episode marked the beginning of a period of intense capital flows volatility and global markets uncertainty leading to shifts in firms' access to global credit (Banti and Bose, 2021).
} 
literature on foreign bank lending behavior, this result suggests that regional banks may act as a transmission channel for the exposure of the domestic credit market to the regional financial cycle via their local affiliates, mainly branches in the case of India.

The third contribution of the paper highlights that while the literature has studied the effectiveness of countries' policy responses to shifts in global financing conditions, little is known about their effectiveness to tackle countries' exposure to regional factors. Given the differences that we find in the exposure of domestic credit markets to regional and global financial cycles, we explore whether specific measures are suitable to mitigate exposure to regional factors. Starting in the aftermath of the GFC, a strand of the literature has documented that macroprudential policies (MPs) provide some respite from global liquidity (Habermeier, Kokenyne and Baba, 2011; Ostry et al., 2012; Bruno, Shim and Shin, 2017; Banti and Phylaktis, 2019). Moreover, the large swings in capital flows associated with the global financial cycle may have weakened the effectiveness of currency regimes for monetary policy autonomy (Rey, 2013; Dées and Galesi, 2021). Taking a more nuanced stance, Obstfeld (2015) argues that countries that employ a flexible exchange rate regime can rely on independent monetary policy to a certain extent. Studying the synchronization of domestic financial cycles in a set of advanced economies, Jordà et al., (2019) document that the exposure to a global financial cycle is more muted, although still sizable, in floating as opposed to fixed currency regimes. Finally, there is also mixed evidence in the literature about the effectiveness of capital account controls to reduce the impact of capital flows towards EMs (Forbes, Fratzscher and Straub, 2015; Bhattarai, Chatterjee and Park, 2020). We contribute to this literature by documenting a relatively stronger effectiveness of these policy tools to tackle regional financial cycles. In particular, we show that MPs do mitigate the exposure of domestic credit markets to liquidity shifts that originate regionally. This is especially interesting given the main use of bank-based MPs in India as opposed to FX-based MPs that appears to be appropriate given the domestic currency dimension of the exposure to the regional financial cycle that we document. We also provide some support to the more nuanced view on currency regime effectiveness and show how targeted capital account controls and a floating currency can reduce the exposure of domestic credit markets to the regional financial cycle.

The rest of the paper is organized as follows. Section 2 reviews the related literature. We report data and summary statistics in section 3 . Section 4 presents the empirical analysis and 
section 5 provides additional tests based on other regional lenders and monetary policies. Finally, section 6 concludes the paper.

\section{Background literature}

We place our study in the context of the literature on global financial cycle including its relevance for EMs and international financial integration, and the policy responses to tackle these evolving global conditions.

\subsection{Global financial cycle}

In her seminal work, Rey (2013) argues that there is a common component, termed as the global financial cycle, in asset prices, capital flows and credit growth around the world, which originates in the US and captures risk aversion in global markets. Since then, few papers have investigated the dynamics and relevance of the global financial cycle for different countries around the world. Amiti, McGuire and Weinstein (2019) find that the explanatory power of the global financial cycle for bank flows is time-varying and it has become weaker in the post-GFC period. Arregui et al. (2018) also find that although the global financial cycle is relevant, its importance has not changed over time. Further, Di Giovanni et al. (2019) show that over 40\% of domestic credit cyclical growth in Turkey can be explained by the global financial cycle, as measured by the VIX. Focusing on unexpected shifts to the VIX, Bhattarai, Chatterjee and Park (2020) document that several EMs financial variables, including the exchange rate and capital inflows, are negatively affected by a shock to US uncertainty. For India, Prabheesh, Anglingkusumo and Juhro (2021) show that the domestic credit cycle is affected by the global financial cycle through domestic currency dynamics.

The presence of a global financial cycle driving capital flows around the world is especially relevant for EMs that are left to tackle the effect of global liquidity on their own. Relying on a set of measures and estimations of the global financial cycle, Cerutti, Claessens and Rose (2019) document the relatively lower power of the global financial cycle to explain capital flows but highlights its importance for the credit markets. Aldasoro et al. (2020) show that the global financial cycle explains larger variations of capital flows to advanced economies than to EMs. However, they find that the explanatory power of an "emerging market" financial cycle is higher for EMs than the global financial cycle. Moreover, Adarov (2020) documents significant synchronization of domestic financial cycles at regional level. 


\subsection{Policy responses to global shocks}

There is a large literature on the effectiveness of various policy responses to manage the impact of global financing conditions on capital flows and domestic markets. Countries can insulate their economies from external shocks via capital controls or macroprudential policies (MPs). MPs comprise of prudential measures other than monetary policy designed at safeguarding and promoting financial stability at both institutional and systemic level (International Monetary Fund, 2017). These measures have attracted renewed interest from policymakers and academia in advanced economies especially in the aftermath of the GFC, although they were already in use across several EMs (Galati and Moessner, 2013). Under the MPs umbrella, we can find a wide range of measures. There are measures that are directly targeted at the banking sector, as it is the case for capital requirements; other measures target borrowers directly, for instance with limits to the loan-to-value ratio; finally, some measures are currency-based or FX tools, in the form for example of limitations to FX loans by banks.

Evidence shows that MPs are generally effective at reducing domestic credit growth (Lim et al., 2011; Ostry et al., 2012; Cerutti, Claessens and Laeven, 2017). Given the destabilizing effect that capital flows can have during episodes of turmoil, a strand of the literature has investigated whether and to what extent MPs mitigate countries' exposure to capital flows. Banti and Phylaktis (2019) find that selected MP tools reduce the impact of global liquidity shocks on house prices. Eller et al. (2021) document a significant effect, as MP tightening reduces domestic credit growth and capital flows and their volatility, especially when adopted in a low-interest rate environment. Concentrating on Asia-Pacific countries, Bruno, Shim and Shin (2017) report that MPs effectively manage bank flows. Frost, Ito and van Stralen (2020) find that MPs reduce capital inflows in a large set of 83 countries. Exploring a loan-level dataset for Romania, Epure et al. (2018) document a similarly positive effect of MPs on domestic credit dynamics especially when global financial conditions are permissive. While they support the general findings, Beirne and Friedrich (2017) show that MPs effectiveness depends on the banking structure. Regulations are more effective at managing capital flows in systems with higher quality and sounder banking systems. Further, some authors find that FX-based MPs are effective at tackling FX bank lending (Lim et al., 2011; Ostry et al., 2012). Ahnert et al. (2021) show that banks' exposure to the global financial cycle is effectively reduced by FX-based MP actions, although the exposure appears to shift to other 
sectors of the financial system. Finally, there is evidence of circumvention and regulatory arbitrage, mostly via local affiliates of foreign banks (Cerutti and Zhou, 2018).

Capital controls are designed to reduce capital flows. Restrictions to the capital account can be targeted at specific types of flows, such as portfolio flows, other (mainly banking) flows, etc. The evidence on the effectiveness of capital controls to manage capital flows is mixed. While MP measures targeting capital flows are generally effective, Frost, Ito and van Stralen (2020) do not find any evidence of capital controls reducing or changing the composition of capital flows. Similarly, Forbes, Fratzscher and Straub (2015) show that capital flow management tools are not generally successful. Bhattarai, Chatterjee and Park (2020) find evidence that countries' exposure to global shocks differ depending on their monetary policy responses, as well as attitude towards capital flows as reflected in capital controls. Interestingly, conducting a textual analysis of Central Bank policy minutes, they note that Asian countries, including India, are particularly attentive to capital flows dynamics and thus their policy actions are more responsive to global shocks than countries in other regions, such as Latin America.

Studying the international trilemma, Rey (2013) argues that the presence of a global financial cycle leaves countries unable to pursue independent monetary policy irrespective of their currency regimes, as long as their capital accounts are open. She argues for a dilemma as opposed to the standard trilemma in international macroeconomics. Identifying the US monetary policy as key driver of the global financial cycle, Dées and Galesi (2021) find that the complex interactions in international financial markets amplify the exposure of countries to this factor. In line with Rey (2013), they find a weak role of currency regimes to shield countries from the global financial cycle. Taking a more nuanced stance, Obstfeld (2015) argues that countries that employ a flexible exchange rate regime can rely on independent monetary policy to a certain extent, at least to influence the short end of the term structure of the interest rates. He agrees that the long-term interest rates are largely driven by a global common factor irrespective of the currency regime. More recently, Dées and Galesi (2021) show that countries' exposure to the global financial cycle increases as they become more globally integrated. Integration in global financial markets makes countries more exposed to not only financial spillovers from advanced countries, but also from EMs (International Monetary Fund, 2016). 


\subsection{Financial integration in regional and global markets}

Lane and Milesi-Ferretti (2018) show that international financial integration for EMs is relatively low $(13 \%)$ if compared with their share of world output (40\%). Focusing on international banking integration post-GFC, Bouvatier and Delatte (2015) document declining international presence of Euro area banks, but an increasing integration from non-Euro area banks. Greater banking integration is mostly associated with common language, higher financial openness (Chinn-Ito index) and physical proximity. Similarly, Eichengreen and Park (2005) show that international banking linkages are associated with physical distance and common language, but not with a common border indicating importance of information costs as opposed to transportation costs (that is more relevant for trade linkages). Kubelec and Sá (2012) build a unique dataset of bilateral holdings for 18 countries for the period 1980-2005 and show using a gravity model that proximity and other proxies of information asymmetry explain bilateral asset stocks and flows similar to trade flows. Moreover, creditors systematically lend more to countries with closer trade links. Thus, the evidence on the importance of similarity and proximity suggests an important role of regional financial integration as opposed to global linkages.

Park and Shin (2009) note that regional financial integration in East Asia has not expanded at the same pace as regional economic integration. East Asian countries have integrated financially in the global system with primarily the US and EU, but financial integration within the region has grown slowly (as measured by co-movement in stock prices with data up to 2006). This is also confirmed by Eichengreen and Park (2005) and Kim, Lee and Shin (2008) who document lower integration in Asia than in the Europe. Focusing on equity markets over the period of 2006 to 2013, Raddant and Kenett (2021) show that Asian equity markets are relatively segmented from global equity markets, and present some regional linkages. Looking at different asset classes may provide different answers, as McCauley, Fung and Gadanecz (2002) find that regional banks and investors are generally holders of Asian bonds and syndicated loans in the region resulting in higher financial integration over time. Importantly, Kubelec and Sá (2012) show that differently from trade flows that give rise to intra-continental clusters, financial linkages are dominated by few key hubs namely the US and UK. This indicates that there are important differences between economic and financial integrations. 
Turning to an investigation of time-variation in financial integration, Yu, Fung and Tam (2010) document increasing integration in equity markets in the region with a variety of indicators in the period leading to the GFC (that is the end of their sample). Fry-McKibbin, Hsiao and Martin (2018) show that financial integration of stock markets with the US and China has generally increased over time, with declines during the GFC and in the latter period of their sample until 2016. They find that financial integration has deteriorated to post-Asian crisis levels from 2014-2016 and key determinants of the level of regional integration are the developments in the Chinese economy.

\section{Data and summary statistics}

\subsection{Firm-level dataset}

We employ a dataset covering profit and loss and balance sheet data assembled by Centre for Monitoring Indian Economy (CMIE) in their Prowess database. The Prowess database covers over 40,000 Indian companies comprising of different sizes, ownership groups, and operating in a wide variety of sectors, such as manufacturing, utilities, resources, and services. ${ }^{8}$ Following normal selection criteria, observations in the $1 \%$ from upper and lower tails of the distribution of the firmlevel financial variables are winsorised to control for outliers. Finally, the panel has an unbalanced structure of 24,169 non-financial Indian firms for the period of 2001-2019.

In our analysis, the main dependent variables are firms' domestic debt ratio and FX debt ratio calculated as the ratio of domestic bank borrowings over total debt and proceeds from foreign currency borrowings (in INR million) over total debt, respectively. ${ }^{9}$ Moreover, we include several firm-level controls in line with Banti and Bose (2021) such as firm size, measured as log real total assets. Firms that are larger in size are able to cope well with financial constraints and have greater access to external finance (Bose, Mallick, and Tsoukas, 2020; Bose, MacDonald, and Tsoukas, 2019). Hence, we expect size to be positively associated with access to domestic and foreign currency borrowings. Liquidity is measured by the quick ratio calculated as the ratio of quick assets

\footnotetext{
${ }^{8}$ See www.cmie.com for more information on the Prowess database, which has been widely used in several studies such as Gormley (2010), Allen et al. (2012), Acharya and Vij (2020) and Banti and Bose (2021).

${ }^{9}$ Domestic borrowing from banks captures the outstanding value of funds raised by a company through banks, which may be secured or unsecured. Foreign currency borrowing (reported in in INR million) is defined in the Prowess database as any loan taken by the company in a currency other than in Indian rupees. Examples of such loans are commercial bank loans, Floating Rate Notes, etc. They also include credit from official export credit agencies and commercial borrowing from the private sector window of multilateral financial institutions such as IBRD, World Bank and Asian Development Bank. Suppliers' credit is not included here.
} 
to quick liabilities. Higher liquidity might encourage firms to have higher debt ratios due to increased ability to meet short-term obligations (Ozkan, 2001), implying a positive relationship between liquidity and external finance. Tangibility is defined as the ratio of net fixed assets to total real assets. Firms with higher tangibility have higher ability to borrow from external financial markets. Finally, export firm is a dummy that takes the value of one if a firm has positive export sales, and zero otherwise. Beck, Demirgüç-Kunt, and Maksimovic (2008) highlight that exporting firms use more external finance compared to non-exporting firms. We expect a positive relationship between firms' borrowings and their liquidity, tangibility and exporting status.

\subsection{Regional variables}

Given our focus on the dynamics of domestic credit markets, we estimate the regional financial cycle in Asia by focusing on the commonality of cross-border bank flows to the region (Cerutti, Claessens and Rose, 2019). Our regional sample includes China, Hong Kong SAR, India, Indonesia, Korea, Malaysia, Philippines, Singapore, Taiwan, Thailand, and Vietnam. We obtain the series of cross-border claims for all reporting banks to all sectors from the Bank for International Settlements (BIS) Consolidated Banking Statistics, and then take the first differences to measure bank flows.

As regional drivers of bank flows commonality, we focus on a series of supply-side factors originating from the main lenders in the region. In line with Koch and Remolona (2018), we consider the following countries as key lenders- Australia, Hong Kong SAR, Japan, Korea, Taiwan, and Singapore. Due to the limited literature on regional factors, we adopt the literature on global factors to identify the corresponding regional measures for the key lenders that helps us to control for the supply-side factors. We then average the measures among the lender countries to build the series of regional factors. Moreover, to capture the relative contribution of individual lender countries on the regional linkages, we also consider the largest lenders individually such as Japan, Australia and Singapore. We consider the Japanese measures separately, since Japan is the largest single lender to India in the region. We focus on Australia as it is the second largest lender to India according to the BIS data. Further, Raddant and Kenett (2021) analyze co-movement in equity prices around the world and find a strong linkage between India and Singapore. Hence, we also include Singapore separately. Finally, given the strong evidence of increasing cross-border bank flows from China in the region (International Monetary Fund, 2015), we consider the special 
case of China in a separate section. In all the specifications, we control for global factors by employing the corresponding US-based measures.

Given our focus on the cross-border bank flows, we follow the empirical literature and employ interbank rate as a measure of funding constraints in the regional banking sectors (Cerutti, Claessens and Ratnovski, 2017; Banti and Phylaktis, 2019). We obtain the money market interbank rates for the key lenders from the OECD database. We expect corporate borrowings to decline when interbank rates increase as tighter funding costs in interbank markets lead to a contraction in the domestic supply of credit. Next, in order to assess the role of regional monetary policy, we employ the yield spreads and policy rates of lender countries. The yield spread is the difference between the 10-year and the 2-year government bond yields, and it measures the steepness of the yield curve. As banks borrow short-term to lend in the long-term, banks engage in "search for yield" when the yield curve flattens (Turner, 2014; Cerutti, Claessens and Ratnovski, 2017). We obtain the yield spreads from DataStream. Given their impact on banks profitability and funding costs, we expect the yield spread to be negatively related to corporate borrowings. Moreover, we take the official policy rates of the main lenders in the region as indicator for the regional monetary policy stance (Cerutti, Claessens and Ratnovski, 2017), and this data is obtained from the IMF's International Financial Statistics (IFS) database. We expect the policy rate to be negatively related to corporate borrowings.

Finally, uncertainty in the US monetary policy triggered large capital flows from EMs during the taper tantrum episode of May 2013 (Bank for International Settlements, 2013). Hence, to account for this factor, we employ a proxy of monetary policy uncertainty in Japan, controlling for uncertainty in the US. We expect corporate borrowings to decline with greater uncertainty. We measure Japanese monetary policy uncertainty with the indicator developed by Arbatli et al. (2019) based on the methodology in Baker, Bloom and Davis (2016). The US monetary policy uncertainty measure is from Baker, Bloom and Davis (2016). ${ }^{10}$ The taper tantrum episode also marked the divergence of monetary policy between the US and other advanced economies altering the sensitivities of bank flows and corporate debt to global liquidity (Avdjiev et al., 2020; Banti and Bose, 2021). Following Avdjiev et al. (2020), we measure the monetary policy divergence

\footnotetext{
10 These measures are constructed from textual analysis of major newspapers in the relative country to identify the frequency of the use of selected key terms in the text of the articles and are available at www.PolicyUncertainty.com.
} 
between the main lender Japan and the US with the difference between the 3-month Euro-dollar and Euro-Yen futures.

\subsection{Policy measures to manage the regional financial cycle}

Borrowing from the literature on countries' exposure to global liquidity and capital flows, we focus on a series of measures that countries can adopt to shield their economies from regional shocks. The effectiveness of these measures depends on their ability to influence the transmission channels of the regional financial cycle in domestic credit markets.

If the source of the shocks is external to the domestic financial system, then the imposition of capital controls or FX-based MPs can help to manage the exposure of domestic credit markets. While capital controls are targeted specifically at foreign investors, FX-based MPs target the FX operations of domestic banks. Hence, these measures potentially restrict domestic banks' borrowings as well as their lending activity in FX. While the latter would not be directly related to domestic corporate debt, the former is directly related to the exposure of domestic banks to the regional financial cycle via the interbank market. Aimed at strengthening the domestic banking sector and curbing domestic credit growth, non-FX MPs can also help in mitigating the exposure of domestic credit markets to regional shocks. For instance, limiting domestic bank lending activity and borrowers' access to credit, MPs can curb the exposure of corporate borrowings by reducing it directly or indirectly. Making the domestic banking sector more resilient also helps to reduce their exposure to external sources of funding. However, these policy actions could have unintended consequences. Imposing limits on domestic banks' lending activity can encourage affiliates of foreign banks to step in (Cerutti and Zhou, 2018). Hence, MPs can shift the source of the transmission channel to different actors in the banking sector rather than manage the exposure of domestic credit (Ahnert et al., 2021). Following the literature, we expect the impact of the regional financial cycle on domestic credit markets to decline with MPs. We employ the aggregated macroprudential policy (MP) measure from the IMF's integrated Macroprudential Policy (iMaPP) database, originally constructed by Alam et al. (2019) up to 2018. We take the sum of all policy actions in a year, measured as +1 for each tightening and -1 for each loosening policy action. Hence, the indicator measures the strength of the MP stance in each year. Looking at the disaggregated data, the most common actions adopted in India are bank reserve requirements and capital requirements. There is little evidence of the use of FX-based MP, with the exception of 
four policy actions in 18 years on limits to open FX positions, exposure and funding, including limits on FX mismatches. Hence, we expect the role of FX-based MP measures to be limited in the context of our study.

In addition to MPs, we consider capital account controls. The common indicators adopted in the literature such as the Ito-Chinn index and the Fernández et al. (2015) index do not vary overtime for our sample on India. Hence, we employ the degree of sectoral openness in the economy by identifying the sectors that are precluded or restricted to foreign investors. We use the information provided by the World Bank on the ease of starting a foreign investment in various sectors. The sectors with higher restrictions for foreign investments in India include agriculture and forestry, media, telecommunication, and transportation. If capital controls are effective, we expect the impact of the regional financial cycle to be stronger for less restricted sectors of the economy.

Finally, countries may rely on their currency regime to shield domestic monetary policy from external shocks, allowing their currency to freely float (Jordà et al., 2019). However, Rey (2013) questions whether countries' growing exposure to the global financial cycle has reduced the ability of currency regime to effectively mitigate these exposures to global shocks. We consider the impact of FX policy by classifying periods of FX interventions in the Indian rupee according to the methodology developed by Shambaugh (2004). Using FX market data from Datastream, we construct a measure of exchange rate regime by considering the currency pegged in a particular year if the exchange rate of the Indian rupee versus the US dollar has fluctuated in a tight band of $+/-2 \%$ in that year. As evidence of an effective currency regime, we expect a weaker impact of the regional financial cycle when the currency regime is freely floating.

\subsection{Other macro controls}

In our specifications we control for domestic determinants of bank credit. In particular, we include the domestic real GDP growth to measure the economic performance of the Indian economy. ${ }^{11} \mathrm{We}$ collect this data from the IMF WEO. We consider the stock returns as an indicator for asset market performance. We measure stock returns as the annual log return of the stock market index and this data comes from DataStream. Finally, we control for the Indian interbank rate to isolate the impact

\footnotetext{
${ }^{11}$ Our results hold when we employ the HP filtered GDP as an alternative measure for the domestic business cycle.
} 
of regional and global factors on domestic borrowings aside from the impact on the domestic bank funding conditions. We collect this information from the OECD database. Overall, we expect corporate borrowings to increase with the real GDP growth and the stock market returns, and to decline with interbank rates.

\subsection{Summary statistics}

Table 1 reports the descriptive statistics for all the variables used in our analysis. We report mean, median and standard deviations for the whole sample in columns 1-3, respectively. Looking at the firm-level debt variables, we find that the proportion of domestic bank debt in total debt is much higher than the proportion of foreign debt. The median domestic bank debt to total debt is 0.72 , while the ratio of foreign currency to total debt is 0.29 for the median firm-year. There is a wide variance in the foreign currency ratio with the standard deviation of 0.33 , very close to the median, also observed by Acharya and Vij (2020).

Turning to the regional and global factors, interbank rates in the region are higher than in the US on average, indicating more stringent funding conditions in the region. Looking at the individual countries in the region, we see that interbank rates are especially higher in Australia but lower in both Japan and Singapore, than the average level in the US. Yield spreads are generally positive in both Asian countries and in the US, as expected. However, average yield spreads are far greater in the region than in the US, indicating steeper yield curves in the Asian countries. The yield curve is especially steep in Australia and Singapore, but almost flat in Japan. Moreover, regional policy rates are generally higher than the US Fed Funds rate, although the US Fed Funds rates vary more. Policy rates are especially higher in Australia, but relatively lower in Japan and Singapore. Looking at Indian MPs, we see that Indian authorities have adopted an annual average of 1.66 policy actions. There is evidence of capital controls implemented in India, with an average share of foreign ownerships across the sectors of the Indian economy restricted to $89.56 \%$. Finally, while the Indian rupee is generally freely floating, there is evidence of periods of FX management, as the average value of the exchange rate regime measure is 0.40 , closer to 0 (floating currency) as opposed to 1 (pegged currency).

As preliminary evidence of co-movement in bank flows in the region, we conduct a pairwise correlation analysis. Specifically, we calculate the bank flows correlation of each country visa-vis the other countries individually and then we report the average correlation coefficients in 
Table 2. We find preliminary evidence of significant commonality in capital flows in the region, with correlation coefficients greater than $30 \%$ in all countries except Philippines with lower average correlation of $19 \%$. These correlations only capture the contemporaneous co-movement of financial cycles, hence in the empirical analysis below we employ a dynamic factor model to explore the developments of these co-movements.

\section{Empirical model and findings}

\subsection{Regional financial cycle in Asia}

In the spirit of Cerutti, Claessens and Rose (2019) and Miranda-Agrippino and Rey (2020), we build a measure of regional financial cycle by estimating a dynamic factor model and extracting a common factor from bank flows to the countries in the region. This sample includes China, Hong Kong SAR, India, Indonesia, Korea, Malaysia, Philippines, Singapore, Taiwan, Thailand, and Vietnam. This regional financial cycle captures the commonality of the financing conditions in the countries. We follow the methodology in Miranda-Agrippino and Rey (2020) and model the series of bank flows as function of a common factor to capture the systematic variation and an idiosyncratic factor that is country-specific. We model the common factor to follow an AR(1) process..$^{12}$ In addition, we build a measure for the global financial cycle by estimating a dynamic factor model of the bank flows to all countries whose data is available in the BIS Consolidated Banking Statistics database. This global sample comprises of 158 countries.

Next, we plot the regional financial cycle together with the global financial cycle in Figure 1. The regional financial cycle exhibits strong variations as compared to global financial cycle with larger downswings especially during the episodes of market turbulence such as the GFC in 2008-2009 and the economic slowdown in China during 2015 and 2018. Although the dynamics between the regional and global financial cycles appear quite similar, the regional cycle is characterized by deeper cyclical upswings and downswings. We find that the correlation between the two series is around 64\%. Contrasting to most studies in the literature on the global financial cycle (Cerutti, Claessens and Rose, 2019; Adarov, 2020; Aldasoro et al., 2020), we are not interested in the explanatory power of the regional cycle on capital flows per se, but instead aim

\footnotetext{
${ }^{12}$ We estimate our model by maximum likelihood with the Berndt-Hall-Hall-Hausman (BHHH) technique.
} 
to determine the relevance of the regional financial cycle for credit markets in the Asian region, and whether countries are able to manage this exposure using different macroeconomic policies.

\subsection{Regional financial cycle and domestic credit markets}

In this section, we estimate the impact of the regional financial cycle on corporate debt in India. Given that bank flow commonality in the region may also arise from countries' common exposure to the global financial cycle, we control for the global financial cycle in our specifications and estimate the following models:

$$
\begin{aligned}
& \frac{\text { Domestic debt }}{\text { Total debt }}_{\text {it }}=a_{0}+a_{1} \text { RFC }_{t-1}+a_{2} G F C y_{t-1}+a_{3} F F_{i t-1}+a_{4} D F_{t-1}+f_{i}+\varepsilon_{i, t} \\
& \frac{\text { Total debt }}{\text { Tot }}_{\text {Tot }}=b_{0}+b_{1} \text { RFC }_{t-1}+b_{2} G F C y_{t-1}+b_{3} F F_{i t-1}+b_{4} D F_{t-1}+f_{i}+\varepsilon_{i, t}
\end{aligned}
$$

where $i=1,2, \ldots, N$ refers to the cross-section of units (firms in this case) at time $t$. The dependent variables are the ratios of domestic bank debt over total debt $\left(\frac{\text { Domestic debt }}{\text { Total debt }}\right)$ and proceeds from foreign currency $(\mathrm{FX})$ borrowings over total debt $\left(\frac{F X \text { debt }}{\text { Total debt }}\right)$. The main variables of interest in these models are the regional financial cycle $(R F C y)$ and global financial cycle $(G F C y)$. FF is a vector of firm-specific characteristics such as size, liquidity, tangibility, and export firm status, and DF is a vector of domestic factors to account for demand-side considerations of credit such as GDP growth, stock returns, and interbank rate. All explanatory variables are lagged one period to reduce possible simultaneity problems. ${ }^{13}$ Finally, we include firm-level $\left(f_{i}\right)$ fixed effects to control for firm heterogeneity.

Table 3 reports the results of the baseline models provided in equations (1) and (2). We report the results for domestic bank debt ratio in columns 1-2, followed by the results of FX debt ratio in columns 3-4 of Table 3. We find a positive and significant effect of the regional financial cycle on firms' domestic bank debt, even after controlling for the global financial cycle. ${ }^{14}$ We do not find any evidence of significant impact of the global financial cycle on domestic corporate debt. Turning to the results of FX debt, we find a positive and significant effect of the global financial cycle on FX debt with no significant impact of the regional financial cycle. We find these

\footnotetext{
${ }^{13}$ We provide the correlation matrix of all control variables used in the empirical models in Table A1 of the Appendix. ${ }^{14} \mathrm{We}$ also confirm our main findings by removing the GFC period from our sample. These results are not reported in the paper for brevity but are available upon request from the authors.
} 
effects to be economically significant. For instance, controlling for the global financial cycle in column 2, we find a one unit increase in regional financial cycle increases domestic bank borrowings by $1.9 \%$. Similarly, the economic magnitudes in column 4 show a one unit increase in global financial cycle increases FX borrowings by $22.3 \%$.

These findings show evidence of considerable regional financial integration in credit markets. They also indicate that the exposure to global and regional financial cycles is associated with different sectors of the financial system, stressing the importance of studying disaggregated data for corporate borrowings as opposed to aggregated corporate debt or leverage. In particular, we show that regional financial integration is related to the domestic banking sector in India that plays a key role in the exposure of corporate debt to the regional financial cycle. On the other hand, FX debt, which includes foreign bank lending and international bond issuances, is related to global financing conditions as opposed to the regional ones.

Moving to firm-level and other macro control variables, we find a positive and significant impact of firms' size, liquidity, tangibility and export firm status on domestic and foreign borrowings suggesting that larger, creditworthy and exporting firms have better access to external finance. Finally, we find that firms are able to access higher domestic bank borrowings when the domestic economy improves as indicated by a higher GDP, when the stock market performance is positive as indicated by higher stock return, and when funding costs in the domestic interbank market are low as indicated by lower interbank rate.

\subsection{Focus on the regional drivers of the financial cycle}

In this section, we turn the attention to the specific drivers of the regional financial cycle by analyzing the exposure of domestic and FX credit markets in India to bank funding conditions and monetary policies in the main regional lending countries. ${ }^{15}$ Specifically, we re-estimate equations (1) and (2) by substituting the regional financial cycle (RFCy) and global financial cycle (GFCy) with different regional and global factors. The regional factors include the regional interbank rate, regional yield spread and regional policy rate, while the global factors include the corresponding US interbank rate, US yield spread and US policy rate.

\footnotetext{
${ }^{15}$ We report the estimation showing the impact of regional factors on the regional financial cycle in Table A2 of the Appendix.
} 
We report the results for domestic bank debt ratio in columns 1-3, followed by the results of FX debt ratio in columns 4-6 of Table 4. Focusing on the conditions of the banking sector of key lenders in the region, we find an increase in domestic debt when the interbank rates in the region decline, controlling for domestic and global interbank rates. Turning to the monetary policy factors, we find a significant impact of regional yield spreads on domestic debt showing a decline in corporate debt when the yield curve steepens, and the monetary policy tightens across key lender countries in the region. The economic magnitudes in columns 1-3 suggest that one unit increases in regional interbank rate, yield spreads and policy rate reduce domestic bank borrowings by $1.6 \%, 0.9 \%$ and $2.8 \%$, respectively.

Among the global factors reported in Table 4, we find a significant impact of only the US interbank rate on domestic corporate debt, and the effect is much weaker in magnitude than the regional one. ${ }^{16}$ We find no significant impact of the US yield spread and policy rate on domestic corporate debt. Focusing on FX debt, we find significant and negative effects of the global factors on FX debt indicating a decline in FX debt when the US interbank rates are higher, the US yield curve steepens, and the US monetary policy tightens. The economic magnitudes in columns 4-6 suggest that a one unit increase in US interbank rate, yield spreads and policy rate reduce foreign borrowings by $0.8 \%, 1.1 \%$ and $0.6 \%$, respectively. Finally, the other firm and macro control variables behave as conjectured.

When we extend this analysis further by focusing on the banking conditions in individual regional lending countries in Table 5, we find that domestic corporate debt increases when Japanese, Australian, and Singaporean banking conditions ease and interbank rates decline. However, we find that the Japanese interbank rates have the largest magnitude effect (4.8\%) on the domestic debt as compared to Australia (1.2\%) and Singapore (0.9\%). Focusing on the results of FX debt, we continue to find a significant impact of the global factors with no significant effect of the regional factors.

\footnotetext{
${ }^{16}$ To account for the bilateral trade linkages between India and the UK, we consider the UK factors as alternative measures for the global (US) factors. We find that results for the regional financial cycle using this global measure are qualitatively and quantitatively similar to the main results provided in the paper. We do not report these results for brevity but they are available upon request from the authors.
} 
Next, in Table 6 we focus on the different indicators of regional monetary policy across Japan, Australia and Singapore. We find a negative and significant impact of yield spread and policy rate on domestic corporate debt, implying a decline in domestic debt when the yield curve steepens and the monetary policy tightens in all the countries, with the strongest effect originating from Japan. With respect to FX debt, we find significant impact of only the global factors with no significant effect of the regional factors.

Turning to the monetary policy uncertainty, we find that both domestic and FX debt declines when there is monetary policy uncertainty in the Japan and US. In this case, the effect is stronger for the US factor. This is consistent with the evidence from the 2013 taper tantrum episode whereby the US monetary policy uncertainty triggered capital flow reversals in EMs (Bank for International Settlements, 2013). This finding is particularly relevant for EMs given the expected change in the stance of US monetary policy in the near future to respond to the higher inflation triggered by the recovery from the Covid-19 pandemic. ${ }^{17}$

\subsection{Transmission channel of foreign vs domestic banks}

So far, we have documented a significant impact of the regional financial cycle on domestic credit markets. We have also shown that regional interbank markets play a key role in the transmission of this effect. Understanding the transmission channel is especially relevant for the policy implications. If foreign banks are more likely to channel foreign shocks, countries may rely on capital controls or FX-based MP measures to manage their exposure. Else, if it is the domestic banking sector that channels regional factors in domestic credit markets, MP measures targeting the banking sector may be more appropriate.

The Indian banking sector comprises domestic state-owned and private banks, and offices of foreign banks operating as branches (Berger et al., 2008; Gormley, 2010; Allen, Babus and Carletti, 2012). ${ }^{18}$ There are 44 foreign banks operating over 250 branches as of 2020. Recently, foreign banks have been issued licenses to operate as subsidiaries, and in 2020 there are 2 foreign

\footnotetext{
17 The taper tantrum episode has shown that monetary policy spillover effects may originate not only from the uncertainty in US monetary policy but also from the divergence of the monetary policy stance in the US from that of other advanced economies. Hence, we look into the impact of divergence in an additional analysis in section 5.2.

${ }^{18}$ Looking at the banking structure in our sample, we do not find evidence for one or few common lenders dominating the banking sector. Moreover, we have separated the sample of firms based on private and state ownership and we do not find qualitatively different results between the two groups, indicating no particular role of state ownership in the credit market exposure to the regional financial cycle.
} 
subsidiaries from Singapore and Mauritius that commenced operations in December 2018 and March 2019, respectively. To disentangle the effect of domestic versus affiliates of foreign banks, we rely on the insights from the literature that investigates the impact of foreign banks on domestic credit markets. This literature documents how, facing severe information asymmetries on prospective borrowers, foreign banks rely on hard information to lend to domestic firms (Mian, 2006; Berger et al., 2008).

Following this literature, we take advantage of our rich database and test whether the borrowings of more transparent firms exhibit greater exposure to the regional financial cycle. We exploit firm heterogeneity by dividing firms into two groups based on several measures of information transparency and monitoring costs (Beck et al., 2018; Naaraayanan and Nielsen, 2021). We classify a firm as more transparent if it is larger in size and have higher collateral (based on the above-median values of the respective distributions of all the firms in that particular year), if it is audited, and have multiple banking relationships. Also, following the literature, we consider foreign firms and firms that belong to a business group as they are more likely to borrow from a foreign bank (Mian, 2006; Berger et al., 2008). We estimate equations (1) and (2) for more and less transparent firms separately and we report these results in Tables 7-8.

In Table 7, columns 1-8 provide results for domestic debt ratio, followed by the results of FX debt ratio in columns 9-16. We find a positive and significant effect of the regional financial cycle on firms' domestic debt only for larger, audited, higher collateral, and multiple banking firms which are considered more transparent firms with lower monitoring costs, while no significant impact of regional cycle on their counterparts. The economic magnitude suggests that a one unit increase in the regional financial cycle increases domestic corporate debt by $2.7 \%, 2.3 \%, 2.6 \%$ and $3.6 \%$ for larger, audited, higher collateral, and multiple banking firms, respectively. Turning to the results of FX debt ratio, we find a positive and significant effect of the global financial cycle on FX debt only for the more transparent firms with no significant impact on their counterparts. These findings show that firms with hard information are more exposed to the regional and global financial cycles than other firms. Given the evidence in the literature, this suggests that affiliates of foreign banks, that are more likely to rely on hard information, are likely to act as transmission channel for the regional and global financial cycles as opposed to domestic banks. 
Moving to the results reported in Table 8, columns 1-4 provide results for domestic debt ratio, followed by the results of FX debt ratio in columns 5-8. We find a positive and significant effect of the regional financial cycle on firms' domestic debt for all firms irrespective of their ownership and membership to business groups. Turning to the global financial cycle, we find a positive and significant effect of the global financial cycle on corporate FX debt only for those firms that are foreign-owned and part of a group, with no significant impact on their counterparts. These findings are consistent with the evidence in Mian (2006) that differentiate between regional and global banks and show that regional banks rely relatively more on soft information than global banks. Indeed, our results suggest that global banks are more likely to establish banking relationship with those firms that are foreign and part of a group, that are generally more transparent and requiring less monitoring, whereas regional banks do not differentiate among these criteria.

\subsection{Regional financial cycle and policy responses}

In this section, we study the effectiveness of various macroeconomic policies to manage the exposure of credit markets to the regional financial cycle. Specifically, we augment our baseline model provided in equation (1) by interacting the regional financial cycle ( $R F C y)$ with various policy indicators to account for MPs, capital controls and FX regime. In details, we estimate the following equation:

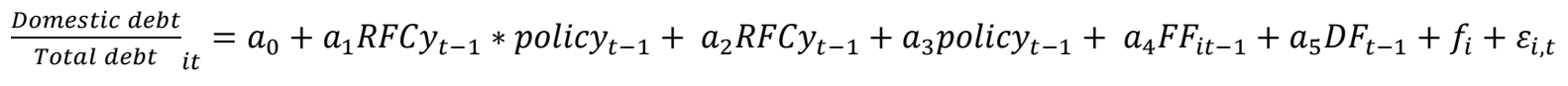

where policy indicates macroprudential policy, sectoral openness, and exchange rate regime. We estimate the equation with one policy measure at a time. Since the baseline results do not show any evidence of a significant impact of the regional financial cycle on FX debt, we do not estimate these regressions for FX borrowings.

We report these results in Table 9. In column 1, we start with the macroprudential policy and find significant evidence of its effectiveness to tackle credit market exposure to the regional financial cycle. In particular, we find that although domestic corporate debt increases with the regional financial cycle, the effect is reduced by MP actions. The economic magnitude suggests that a one standard deviation increase in MP actions reduces the effect of regional financial cycle on domestic corporate debt by $0.8 \%$. 
Turning to the measure of capital controls (sectoral openness) in column 2, we find that the effect of regional financial cycle on domestic corporate debt is stronger in those sectors of the economy that are open to foreign investors. This implies that capital controls that restrict entry of foreign investors in domestic sectors of the economy are effective as a means to shield domestic credit markets from the shifts in regional financing conditions. The economic magnitude suggests that a one standard deviation increase in sectoral openness increases the effect of regional cycle by $7 \%$.

Finally, we document the impact of exchange rate regime in column 3 and find that when authorities manage their currency, that is when exchange rate regime increases, the impact of regional financial cycle on domestic corporate debt is stronger. Hence, we document the effectiveness of floating exchange rate regimes in shielding countries from the regional financial cycle. The economic magnitude suggests that a one standard deviation increase in exchange rate regime increases the effect of regional cycle by $0.9 \%$.

\section{Robustness tests}

\subsection{China as an emerging regional lender}

In this section, we focus specifically on China as an emerging regional lender. ${ }^{19}$ Although we cannot gather the specific contribution of Chinese banks to regional bank flows because China does not report consolidated bank claims to the BIS Consolidated Banking Statistics, evidence suggests that Chinese banks are expanding abroad at a sustained pace (Lane and Milesi-Ferretti, 2018) and they have expanded following the retrenchment of European banks in the post-GFC period alongside banks from advanced economies including Japan (International Monetary Fund, 2015; Bénétrix et al., 2019). ${ }^{20}$ This has led to greater banking integration in Asian countries (International Monetary Fund, 2015) and China, together with Japan, is now a key node for the intermediation of US dollars in Asia (Committee on the Global Financial System, 2020). Moreover, given the magnitude of the Chinese economy and its economic linkages with other countries in the region and all over the world, spillovers from China also arise due to its economic

\footnotetext{
${ }^{19}$ A study of monetary policy in China is provided in Deng et al. (2015).

${ }^{20}$ Data from the BIS Locational Banking Statistics suggest that Chinese banks' foreign claims versus the rest of the world amount to USD 2.4 trillion at the end of 2020, from USD 1.4 trillion at the end of 2015 when its reporting started. Koch and Remolona (2018) mentioned that China is now the third largest provider of US dollar credit to the international banking system.
} 
performance (International Monetary Fund, 2016). Indeed, recent shocks to EMs capital flows have originated in China. Capital flows in EMs have been especially volatile following the economic slowdown in China during 2015 and the escalated trade tensions between China and the US in 2018 (Bank for International Settlements, 2015, 2018). This is also evident in Figure 1 that shows a decline in the regional financial cycle in Asia in these periods.

We report the impact of financing conditions in China on corporate debt in Table 10. We find that tighter bank funding conditions and monetary policy in China significantly reduce domestic corporate debt but does not have any significant impact on FX debt. These results are consistent with the evidence related to other large regional lenders, but the magnitude effect is much smaller than that of other regional lenders (as reported in Tables 5 and 6) which signals an increasing but still relatively limited influence of Chinese factors on credit markets in the region.

\subsection{Monetary policy divergence between Japan and US}

In the main analysis, we document a significant impact of US monetary policy uncertainty on domestic and FX corporate debt. The evidence of the detrimental impact of US monetary policy uncertainty on EMs capital flows is evident from the market events around the 2013 taper tantrum episode. In addition to increased uncertainty with respect to US monetary policy, this episode has also marked the beginning of the divergence of monetary policy between the US and other advanced economies. This divergence had dramatic effects on global credit, altering the sensitivities of bank flows and corporate debt to global liquidity (Avdjiev et al., 2020; Banti and Bose, 2021). Following Avdjiev et al. (2020), we measure the monetary policy divergence between the US and the main lender Japan with the difference between the 3-month Euro-dollar and EuroYen futures. Given the higher prices of Euro-yen futures, the measure divergence is negative. Hence, monetary policy divergence is higher, for lower values of divergence.

We report the results of monetary policy divergence in Table 11. In general, higher monetary policy divergence is associated with higher corporate debt, both domestic and FX. The coefficient of the interaction term "Regional financial cycle*divergence" shows that higher the divergence in the monetary policy between the US and Japan, the stronger is the impact of the regional financial cycle on domestic corporate debt. Turning to FX debt, the divergence has no effect on the exposure to the regional financial cycle that remains insignificant. These findings are particularly relevant for EMs as monetary policy in the major financial centers, including Japan 
and the US, is expected to change in the near future. We show here that it is not only the direction of the policy stance in the major financial centers that is relevant for EMs, but also its convergence or divergence across these major financial systems.

\subsection{Endogeneity concerns}

We use instrumental variable estimations such as two-staged least squares (2SLS) to tackle endogeneity problems in our main estimations. The motivation behind this model is to control for unobserved firm-specific characteristics that might be correlated with the firm's balance sheet conditions and financing structure, especially firms' ability or willingness to hold domestic and foreign debt. We already use lagged independent variables to reduce simultaneity bias in our main specifications. To solve any further concerns of endogeneity, we require observed instruments that are strongly correlated with the firm-level variables but uncorrelated with the error term. Hence, we instrument these variables using their own values lagged twice. It is generally agreed that lagged variables (referred as the 'internal' instruments) are distributed independently of the error process and that they are sufficiently correlated with the included endogenous regressors. Hence, they are frequently used as instruments in the literature (Bose et el., 2019; Banti and Bose, 2021). The validity and relevance of the instruments are verified using a number of diagnostic tests. The under-identification test is distributed as chi-square under the null of under-identification. The Hansen $\mathbf{J}$ statistic is a test of the over-identifying restrictions, distributed as chi-square under the null of instrument validity.

The results of 2SLS are provided in Table 12 and confirm the results from our main estimations. We continue to find a positive and significant effect of the regional financial cycle on firms' domestic debt even after controlling for the global financial cycle, and a significant effect of the global financial cycle on FX debt with no significant impact of the regional financial cycle. Further, we find a positive and significant effect of the regional financial cycle on firms' domestic debt only for firms which are considered more transparent with lower monitoring costs with no significant impact of regional cycle on their counterparts. Finally, we document the effectiveness of macroeconomic policies such as MPs and capital controls and of a floating FX regime to tackle credit market exposure to the regional financial cycle. 


\section{Conclusion}

In this paper, we extend previous work on financial cycles and document the emergence of a regional financial cycle in Asia. The Asian banks have grown to be important providers of credit in the region, and beyond. While there is evidence in the literature of emergence of key lenders from Japan and China, the rise of a regional financial cycle and its implications on the dynamics of domestic credit markets in the region has been neglected in the literature. By exploiting a detailed firm-level dataset of domestic and FX corporate debt for 24,169 non-financial Indian firms over the period 2001-2019, we provide significant evidence of the exposure of domestic credit markets to the regional financial cycle in Asia, comparing and contrasting it with the exposure to the global financial cycle. We find that disentangling the effect of external financing conditions on domestic and FX corporate debt allows for a more precise identification of the influence of external factors on domestic credit markets. In particular, we find that domestic corporate debt is exposed to the regional financial cycle only, whereas the global financial cycle only affects FX corporate debt. With respect to the regional financial cycle, we show that both interbank funding markets and monetary policy in the region act as transmission channels. Consistently with the documented increasing relevance of Japanese banks in cross-border bank flows around the world, we find that Japanese factors have the strongest influence on domestic credit, compared to other regional lenders. In the case of China, we also find evidence of an emerging but still relatively limited effect of Chinese factors. Further, we show that transparent firms with lower monitoring costs are more exposed to the regional financial cycle in the domestic credit markets, signaling a potentially key role of domestic offices of regional banks as transmission channels.

Finally, we build on the evidence related to global factors in the literature and study the policy actions that countries can adopt to manage their exposure to the regional financial cycle. We document that MPs are indeed relatively successful at mitigating the exposure of domestic credit markets to the regional financial cycle. Moreover, we find that the implementation of selective capital controls and floating currency regimes limit the impact of the regional financial cycle on domestic corporate debt. These results underline the importance for policy makers to be vigilant of regional and global financial shocks, thus pointing towards a need for carefully designed policy actions. The evidence we provide on the exposure to regional factors is key in this respect, given the profound differences with respect to EMs exposure to global factors. Thus, our policy implications offer a clear course of action for EMs to manage these exposures. 


\section{References}

Abraham, F., Cortina, J. J. and Schmukler, S. L. (2021) 'The rise of domestic capital markets for corporate financing: Lessons from East Asia', Journal of Banking and Finance, 122.

Acharya, V. V. and Vij, S. (2020) 'Foreign Currency Borrowing of Corporations as Carry Trades: Evidence from India', NBER Working Papers, 28096.

Adarov, A. (2020) 'Financial cycles around the world', International Journal of Finance and Economics, pp. 1-39.

Ahnert, T. et al. (2021) 'Macroprudential FX regulations: Shifting the snowbanks of FX vulnerability?', Journal of Financial Economics, 140(1), pp. 145-174.

Alam, Z. et al. (2019) 'Digging Deeper--Evidence on the Effects of Macroprudential Policies from a New Database', IMF Working Papers, 66.

Aldasoro, I. et al. (2020) 'Global and domestic financial cycles: variations on a theme', BIS Working Papers, 864.

Allen, F. et al. (2012) 'Financing firms in India', Journal of Financial Intermediation, 21(3), pp. 409-445.

Allen, F., Babus, A. and Carletti, E. (2012) 'Asset commonality, debt maturity and systemic risk', Journal of Financial Economics, 104(3), pp. 519-534.

Alter, A. and Elekdag, S. (2020) 'Emerging Market Corporate Leverage and Global Financial Conditions', Journal of Corporate Finance, 62.

Amiti, M., McGuire, P. and Weinstein, D. E. (2019) 'International Bank Flows and the Global Financial Cycle', IMF Economic Review, 67(1), pp. 61-108.

Arbatli, E. C. et al. (2019) 'Policy Uncertainty in Japan', NBER Working Papers, 23411.

Arregui, N. et al. (2018) 'Can Countries Manage Their Financial Conditions Amid Globalization?’, IMF Working Papers, 15.

Avdjiev, S. et al. (2020) 'The Shifting Drivers of Global Liquidity', Journal of International Economics, 125, pp. 1-17.

Avdjiev, S., Chui, M. and Shin, H. S. (2014) 'Non-financial corporations from emerging market economies and capital flows', BIS Quarterly Review, (December), pp. 67-77.

Avdjiev, S. and Hale, G. (2019) 'U.S. monetary policy and fluctuations of international bank lending', Journal of International Money and Finance, 95, pp. 251-268.

Avdjiev, S., McGuire, P. and von Peter, G. (2020) 'International dimensions of EME corporate debt', BIS Quarterly Review, (June), pp. 1-13.

Avdjiev, S. and Takáts, E. (2019) 'Monetary Policy Spillovers and Currency Networks in CrossBorder Bank Lending: Lessons from the 2013 Fed Taper Tantrum’, Review of Finance, 23(5), pp. 993-1029. 
Azis, I. J. and Shin, H. S. (2015) Managing elevated risk: Global liquidity, capital flows, and macroprudential policy - an Asian perspective.

Baker, S. R., Bloom, N. and Davis, S. J. (2016) 'Measuring Economic Policy Uncertainty', Quarterly Journal of Economics, 131(4), pp. 1593-1636.

Banerjee, S. and Mohanty, M. (2021) 'US monetary policy and the financial channel of the exchange rate: evidence from India', BIS Working Papers, 945.

Bank for International Settlements (2013) 'Markets precipitate tightening', BIS Quarterly Review, (September), pp. 1-11.

Bank for International Settlements (2015) 'Uneasy calm awaiting lift-off', BIS Quarterly Review, (December), pp. 1-12.

Bank for International Settlements (2018) 'Divergences widen in markets', BIS Quarterly Review, (September), pp. 1-6.

Banti, C. and Bose, U. (2021) 'Shifts in global credit and corporate access to finance', Journal of Financial Stability, (Forthcoming).

Banti, C. and Phylaktis, K. (2019) 'Global Liquidity, House Prices and Policy Responses', Journal of Financial Stability, 43, pp. 79-96.

Beck, T. et al. (2018) 'When arm's length is too far: Relationship banking over the credit cycle', Journal of Financial Economics, 127(1), pp. 174-196.

Beck, T., Demirgüç-Kunt, A. and Maksimovic, V. (2008) 'Financing Patterns Around the World: Are Small Firms Different?’, Journal of Financial Economics, 89, pp. 467-487.

Beirne, J. and Friedrich, C. (2017) 'Macroprudential policies, capital flows, and the structure of the banking sector', Journal of International Money and Finance, 75, pp. 47-68.

Bekaert, G. et al. (2011) 'What segments equity markets?', Review of Financial Studies, 24(12), pp. 3841-3890.

Bénétrix, A. S. et al. (2019) 'Financial deglobalisation in banking?', Journal of International Money and Finance, 94, pp. 116-131.

Berger, A. N. et al. (2008) 'Bank ownership type and banking relationships', Journal of Financial Intermediation, 17(1), pp. 37-62.

Bhattarai, S., Chatterjee, A. and Park, W. Y. (2020) 'Global spillover effects of US uncertainty', Journal of Monetary Economics, 114, pp. 71-89.

Bose, U., MacDonald, R. and Tsoukas, S. (2019) 'Policy Initiatives and Firms' Access to External Finance: Evidence from a Panel of Emerging Asian Economies', Journal of Corporate Finance, 59, pp. 162-184.

Bouvatier, V. and Delatte, A. L. (2015) 'Waves of international banking integration: A tale of regional differences', European Economic Review, 80, pp. 354-373. 
Bräuning, F. and Ivashina, V. (2020) 'U.S. monetary policy and emerging market credit cycles', Journal of Monetary Economics, 112, pp. 57-76.

Bruno, V., Shim, I. and Shin, H. S. (2017) 'Comparative assessment of macroprudential policies', Journal of Financial Stability, 28, pp. 183-202.

Bruno, V. and Shin, H. S. (2015) 'Cross-Border Banking and Global Liquidity', Review of Economic Studies, 82(2), pp. 535-564.

Buch, C. M. et al. (2019) 'The International Transmission of Monetary Policy', Journal of International Money and Finance, 91, pp. 29-48.

Caballero, J., Panizza, U. and Powell, A. (2016) 'The Second Wave of Global Liquidity: Why Are Firms Acting Like Financial Intermediaries?', Inter-American Development Bank Working Paper Series, 641(April).

Calvo, G. A., Leiderman, L. and Reinhart, C. M. (1993) 'Capital Inflows and Real Exchange Rate Appreciation in Latin America: The Role of External Factors', IMF Staff Papers, 40(1), pp. 108151.

Calvo, G. A., Leiderman, L. and Reinhart, C. M. (1996) 'Inflows of Capital to Developing Countries in the 1990s', Journal of Economic Perspectives, 10(2), pp. 123-139.

Cerutti, E. and Claessens, S. (2017) 'The great cross-border bank deleveraging: Supply constraints and intra-group frictions', Review of Finance, 21(1), pp. 201-236.

Cerutti, E., Claessens, S. and Laeven, L. (2017) 'The Use and Effectiveness of Macroprudential Policies: New Evidence', Journal of Financial Stability, 28, pp. 203-224.

Cerutti, E., Claessens, S. and Ratnovski, L. (2017) 'Global Liquidity and Drivers of Cross-Border Bank Flows’, Economic Policy, 32(89), pp. 81-125.

Cerutti, E., Claessens, S. and Rose, A. K. (2019) 'How Important is the Global Financial Cycle? Evidence from Capital Flows', IMF Economic Review, 67(1), pp. 24-60.

Cerutti, E., Koch, C. and Pradhan, S.-K. (2018) 'The growing footprint of EME banks in the international banking system', BIS Quarterly Review, (December), pp. 27-37.

Cerutti, E. and Zhou, H. (2017) 'The Global Banking Network in the Aftermath of the Crisis: Is There Evidence of De-globalization?', IMF Working Papers, 232.

Cerutti, E. and Zhou, H. (2018) 'Cross-border Banking and the Circumvention of Macroprudential and Capital Control Measures', IMF Working Papers, 217.

Cetorelli, N. and Goldberg, L. S. (2011) 'Global Banks and International Shock Transmission: Evidence from the Crisis', IMF Economic Review, 59(1), pp. 41-76.

Chung, K. et al. (2015) 'Global Liquidity through the Lens of Monetary Aggregates', Economic Policy, 30(82), pp. 231-290.

Committee on the Global Financial System (2020) 'US dollar funding: an international 
perspective', CGFS Papers, 65 .

Correa, R. et al. (2021) 'Cross-Border Bank Flows and Monetary Policy', The Review of Financial Studies, (forthcoming).

Dées, S. and Galesi, A. (2021) 'The Global Financial Cycle and US Monetary Policy in an Interconnected World', Journal of International Money and Finance, (forthcoming).

Deng, Y. et al. (2015) 'China's pseudo-monetary policy', Review of Finance, 19(1), pp. 55-93.

Lo Duca, M., Nicoletti, G. and Vidal Martínez, A. (2016) 'Global corporate bond issuance: What role for US quantitative easing?', Journal of International Money and Finance, 60, pp. 114-150.

Duffee, G. R. and Hördahl, P. (2021) 'Debt specialisation and diversification: International evidence', BIS Working Papers, 928.

Eichengreen, B. and Park, Y. C. (2005) 'Why Has There Been Less Financial Integration in Asia than in Europe?', in Park, Y. C., Takatoshi, I., and Wang, Y. (eds) A New Financial Market Structure for East Asia. UK: Edward Edgar, pp. 84-103.

Eller, M. et al. (2021) 'The impact of macroprudential policies on capital flows in CESEE', Journal of International Money and Finance, (forthcoming).

Epure, M. et al. (2018) 'Household Credit, Global Financial Cycle, and Macroprudential Policies: Credit Register Evidence from an Emerging Country', IMF Working Papers, 13.

Fernández, A. et al. (2015) 'Capital Control Measures: A New Dataset', IMF Working Papers, 80.

Forbes, K., Fratzscher, M. and Straub, R. (2015) 'Capital Controls and Macroprudential Measures: What Are They Good For?', Journal of International Economics, 96(S1), pp. 76-97.

Frost, J., Ito, H. and van Stralen, R. (2020) 'The Effectiveness of Macroprudential Policies and Capital Controls Against Volatile Capital Inflows’, BIS Working Papers, 867.

Fry-McKibbin, R., Hsiao, C. Y. L. and Martin, V. L. (2018) 'Global and regional financial integration in East Asia and the ASEAN', North American Journal of Economics and Finance, 46(March), pp. 202-221.

Galati, G. and Moessner, R. (2013) 'Macroprudential Policy - a Literature Review', Journal of Economic Surveys, 27(5), pp. 846-878.

di Giovanni, J. et al. (2019) 'International Spillovers and Local Credit Cycles', NBER Working Papers, 23149.

Gormley, T. A. (2010) 'The impact of foreign bank entry in emerging markets: Evidence from India', Journal of Financial Intermediation, 19(1), pp. 26-51.

Habermeier, K., Kokenyne, A. and Baba, C. (2011) 'The Effectiveness of Capital Controls and Prudential Policies in Managing Large Inflows', IMF Staff Discussion Note, 14.

Hirata, H., Kose, M. A. and Otrok, C. (2013) 'Regionalization versus Globalization', in Global 
Interdependence, Decoupling, and Recoupling. MIT Press, pp. 87-130.

International Monetary Fund (2015) 'International Banking After the Crisis: Increasingly Local and Safer?', Global Financial Stability Report, April(Chapter 2), pp. 55-91.

International Monetary Fund (2016) 'The growing importance of financial spillovers from emerging market economies', Global Financial Stability Report, April(Chapter 2).

International Monetary Fund (2017) 'Increasing Resilience to Large and Volatile Capital FlowsThe Role of Macroprudential Policies', IMF Policy Papers.

Jordà, Ò. et al. (2019) 'Global Financial Cycles and Risk Premiums', IMF Economic Review, 67(1), pp. 109-150.

Kim, S., Lee, J. W. and Shin, K. (2008) 'Regional and Global Financial Integration in East Asia', in Eichengreen, B., Wyplosz, C., and Park, Y. C. (eds) China, Asia, and the New World Economy. London: Oxford University Press, pp. 1-43.

Koch, C. and Remolona, E. (2018) 'Common lenders in emerging Asia: their changing roles in three crises’, BIS Quarterly Review, (March), pp. 17-28.

Koepke, R. (2019) 'What Drives Capital Flows To Emerging Markets? a Survey of the Empirical Literature', Journal of Economic Surveys, 33(2), pp. 516-540.

Kubelec, C. and Sá, F. (2012) 'The geographical composition of national external balance sheets: 1980-2005', International Journal of Central Banking, 8(2), pp. 143-189.

Lane, P. R. and Milesi-Ferretti, G. M. (2018) 'The External Wealth of Nations Revisited: International Financial Integration in the Aftermath of the Global Financial Crisis', IMF Economic Review, 66(1), pp. 189-222.

Lim, C. et al. (2011) 'Macroprudential Policy: What Instruments and How to Use Them ? Lessons from Country Experiences', IMF Working Papers, 238.

McCauley, R. N., Fung, S.-S. and Gadanecz, B. (2002) 'Integrating the finances of East Asia', BIS Quarterly Review, (December), pp. 83-96.

McCauley, R. N., McGuire, P. and Sushko, V. (2015) 'Global dollar credit: links to US monetary policy and leverage', Economic Policy, 30(82), pp. 187-229.

Mian, A. (2006) 'Distance constraints: The limits of foreign lending in poor economies', Journal of Finance, 61(3), pp. 1465-1505.

Miranda-Agrippino, S. and Rey, H. (2020) 'US Monetary Policy and the Global Financial Cycle', Review of Economic Studies, 87(6), pp. 2754-2776.

Morais, B. et al. (2019) 'The International Bank Lending Channel of Monetary Policy Rates and QE: Credit Supply, Reach-for-Yield, and Real Effects', Journal of Finance, 74(1), pp. 55-90.

Naaraayanan, L. S. and Nielsen, K. M. (2021) 'Does personal liability deter individuals from serving as independent directors?', Journal of Financial Economics, 140(2), pp. 621-643. 
Obstfeld, M. (2015) 'Trilemmas and trade- offs: living with financial globalisation', BIS Working Papers, 480.

Ostry, J. D. et al. (2012) 'Tools for managing financial-stability risks from capital inflows', Journal of International Economics, 88(2), pp. 407-421.

Ozkan, A. (2001) 'Determinants of Capital Structure and Adjustment to Long Run Target: Evidence from UK Company Panel Data', Journal of Business Finance \& Accounting, 28, pp. 175-198.

Park, Y. C. and Shin, K. (2009) 'Economic integration and changes in the business cycle in East Asia: Is the region decoupling from the rest of the world?', Asian Economic Papers, 8(1), pp. 107140.

Prabheesh, K. P., Anglingkusumo, R. and Juhro, S. M. (2021) 'The dynamics of global financial cycle and domestic economic cycles: Evidence from India and Indonesia', Economic Modelling, 94, pp. 831-842.

Raddant, M. and Kenett, D. Y. (2021) 'Interconnectedness in the global financial market', Journal of International Money and Finance, (forthcoming).

Rey, H. (2013) 'Dilemma not Trilemma: The Global Financial Cycle and Monetary Policy Independence', in Federal Reserve of Kansas City Economic Symposium (ed.) Economic Policy Symposium - Jackson Hole.

Shambaugh, J. C. (2004) 'The Effect of Fixed Exchange Rates on Monetary Policy', Quarterly Journal of Economics, 119(February), pp. 300-352.

Turner, P. (2014) 'The global long-term interest rate, financial risks and policy choices in EMEs', BIS Working Papers, 441.

Yu, I. W., Fung, K. P. and Tam, C. S. (2010) 'Assessing financial market integration in Asia Equity markets', Journal of Banking and Finance, 34(12), pp. 2874-2885. 
Figure 1: Regional financial cycle in Asia

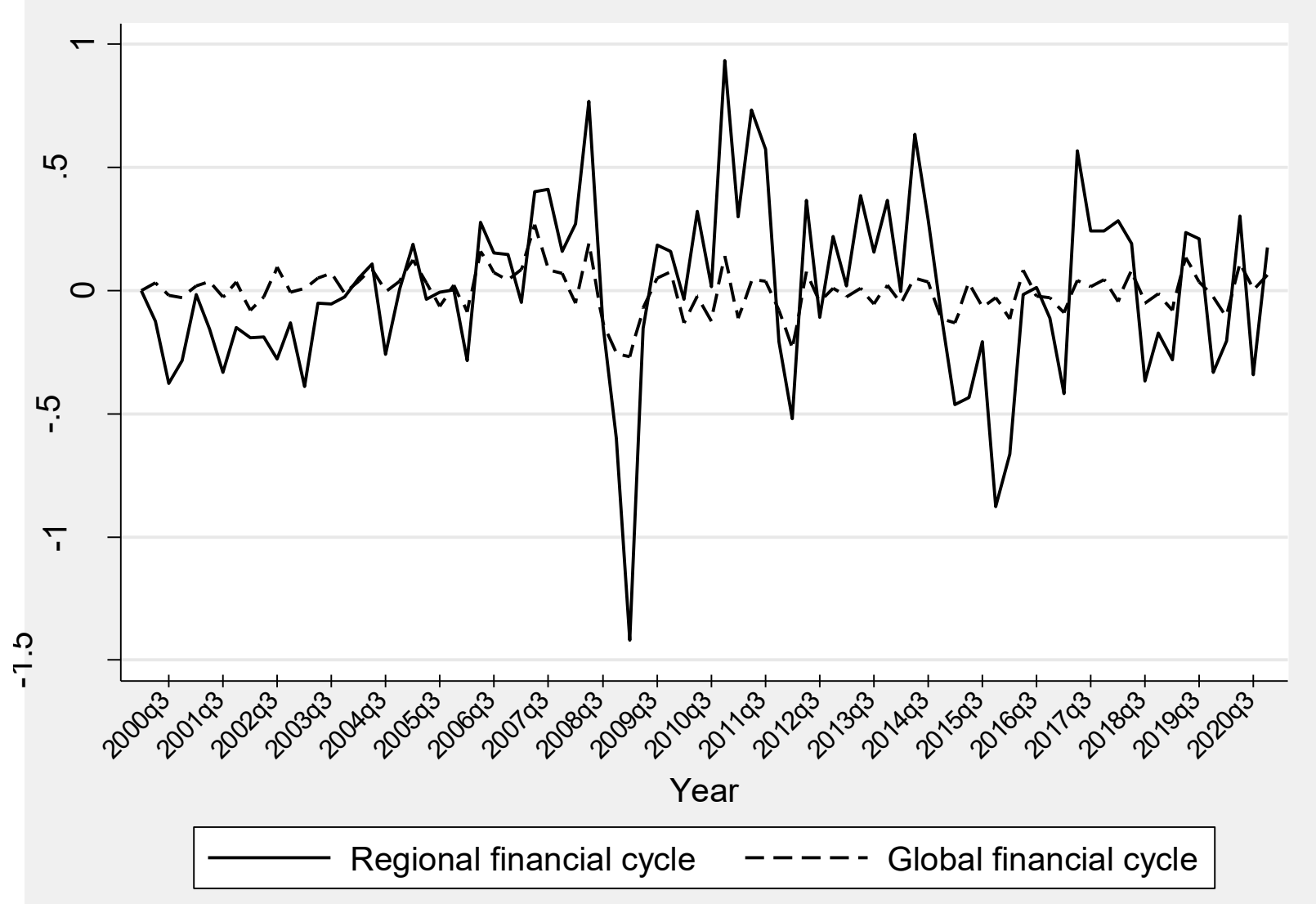

Notes: The figure reports the regional financial cycle (solid line) together with the global financial cycle (dotted line). 
Table 1: Cross-country correlation analysis

\begin{tabular}{cc}
\hline Country & Correlations \\
\hline China & 0.37 \\
Hong Kong SAR & 0.40 \\
India & 0.31 \\
Indonesia & 0.35 \\
Korea & 0.40 \\
Malaysia & 0.36 \\
Philippines & 0.19 \\
Singapore & 0.39 \\
Taiwan & 0.34 \\
Thailand & 0.31 \\
Vietnam & 0.28 \\
\hline
\end{tabular}

Notes: The table reports the average pairwise correlation of bank flows for each country versus the other countries in the region. Bank flows for each country are calculated as the difference in the cross-border bank claims of all BIS reporting banks versus all sectors for each country. 
Table 2: Descriptive statistics

\begin{tabular}{|c|c|c|c|}
\hline & $\begin{array}{c}(1) \\
\text { Mean } \\
\end{array}$ & $\begin{array}{c}(2) \\
\text { Median } \\
\end{array}$ & $\begin{array}{c}(3) \\
\text { Standard Deviation }\end{array}$ \\
\hline \multicolumn{4}{|c|}{ Firm-level measures } \\
\hline Domestic debt/Total debt & 0.65 & 0.72 & 0.32 \\
\hline FX debt/Total debt & 0.39 & 0.29 & 0.33 \\
\hline Size $(\log )$ & 6.52 & 6.43 & 1.95 \\
\hline Liquidity & 1.07 & 0.64 & 2.97 \\
\hline Tangibility & 0.31 & 0.30 & 0.25 \\
\hline Export firm & 0.36 & 0 & 0.48 \\
\hline \multicolumn{4}{|c|}{ Regional factors } \\
\hline Regional interbank rate $(\%)$ & 1.55 & 1.27 & 0.86 \\
\hline Regional yield spread (\%) & 7.99 & 7.22 & 3.77 \\
\hline Regional policy rate (\%) & 1.77 & 1.39 & 0.88 \\
\hline JP interbank rate $(\%)$ & 0.07 & 0.07 & 0.15 \\
\hline AUS interbank rate $(\%)$ & 3.37 & 2.69 & 1.76 \\
\hline SG interbank rate $(\%)$ & 0.85 & 0.50 & 0.86 \\
\hline JP yield spread (\%) & 0.76 & 0.70 & 0.43 \\
\hline AUS yield spread (\%) & 5.78 & 5.90 & 4.22 \\
\hline SG yield spread (\%) & 12.62 & 14.18 & 6.18 \\
\hline JP policy rate $(\%)$ & 0.31 & 0.30 & 0.15 \\
\hline AUS policy rate $(\%)$ & 3.39 & 2.73 & 1.76 \\
\hline SG policy rate $(\%)$ & 0.73 & 0.25 & 0.88 \\
\hline Monetary policy uncertainty (JP) & 114.04 & 110.43 & 36.28 \\
\hline \multicolumn{4}{|c|}{ Global factors } \\
\hline Global financial cycle & -0.01 & -0.01 & 0.04 \\
\hline US interbank rate $(\%)$ & 1.24 & 0.54 & 1.49 \\
\hline US yield spread (\%) & 1.34 & 1.45 & 0.81 \\
\hline US policy rate $(\%)$ & 1.27 & 0.39 & 1.47 \\
\hline Monetary policy uncertainty (US) & 119.81 & 105 & 44.14 \\
\hline \multicolumn{4}{|c|}{ Domestic factors } \\
\hline GDP growth (\%) & 7.19 & 7.41 & 1.85 \\
\hline Stock returns & 0.14 & 0.12 & 0.17 \\
\hline Interbank rate $(\%)$ & 6.78 & 6.25 & 1.16 \\
\hline \multicolumn{4}{|c|}{ Policy actions } \\
\hline Macroprudential policy (MP) & 1.66 & 2 & 2.62 \\
\hline Sectoral openness $(\%)$ & 89.56 & 100 & 23.32 \\
\hline Exchange rate regime & 0.40 & 0 & 0.49 \\
\hline
\end{tabular}

Notes: The table reports the statistics of all variables used in the estimated models. Domestic debt/Total debt is the ratio of proceeds from domestic currency bank borrowings over total debt. $F X$ debt/Total debt is the ratio of proceeds from foreign currency borrowings (in INR million) over total debt. Size is the logarithm of total real assets. Liquidity is the ratio of quick assets to quick liabilities. Tangibility is the ratio of net fixed assets to total real assets. Export firm is a dummy for firms with positive exports, and zero otherwise. Regional interbank rate, JP interbank rate, AUS interbank rate, $S G$ interbank rate is the average money market interbank rate in the region, Japan, Australia, and Singapore, respectively. Regional yield spread, JP yield spread, AUS yield spread, SG yield spread is the average difference between 10-year and 2-year government yields in the region, Japan, Australia, and Singapore, respectively. Regional policy rate, JP policy rate, AUS policy rate, SG policy rate is the average policy rate in the region, Japan, Australia, and Singapore, respectively. Monetary policy uncertainty in Japan (JP) is from Arbatli et al. (2019). Global financial cycle is the first difference of the common factor in bank flows around the world. US interbank rate is the US money market interbank rate. US yield spread is the difference between 10-year and 2-year Treasury yields. US policy rate is the Fed funds rate. Monetary policy uncertainty in the US is from Baker, Bloom and Davis (2016). GDP growth is the annual real GDP growth for India. Stock returns are the log returns of the stock market index of the Indian stock exchange. Interbank rate is the money market interbank rate in India. Macroprudential policy (MP) is the aggregated MP index by Alam et al. (2019) that is the annual sum of policy actions coded as dummies, +1 for tightening and -1 for loosening actions. Sectoral openness is the maximum share of foreign ownership allowed by regulation in the firms' sectors. Exchange rate regime is the Shambaugh (2004) indicator that is a dummy taking the value of 1 for pegged regimes and 0 for floating regimes. 
Table 3: Impact of the regional financial cycle on corporate debt

\begin{tabular}{|c|c|c|c|c|}
\hline & (1) & (2) & (3) & (4) \\
\hline Dependent variable= & \multicolumn{2}{|c|}{ Domestic debt/Total debt } & \multicolumn{2}{|c|}{ FX debt/Total debt } \\
\hline \multirow{2}{*}{ Regional financial cycle } & $0.015^{* * *}$ & $0.019^{* * *}$ & 0.007 & 0.009 \\
\hline & $(5.01)$ & $(6.48)$ & $(0.55)$ & $(0.71)$ \\
\hline \multirow[t]{2}{*}{ Global financial cycle } & - & -0.010 & - & $0.223^{* *}$ \\
\hline & & $(-0.35)$ & & $(2.04)$ \\
\hline \multirow[t]{2}{*}{ Size } & $0.007 * * *$ & $0.010 * * *$ & $0.055 * * *$ & $0.051 * * *$ \\
\hline & $(4.44)$ & $(5.94)$ & $(4.56)$ & $(4.30)$ \\
\hline \multirow[t]{2}{*}{ Liquidity } & $0.001 *$ & $0.001 *$ & $0.005 * * *$ & $0.005 * * *$ \\
\hline & $(1.79)$ & $(1.85)$ & $(3.05)$ & $(3.03)$ \\
\hline \multirow[t]{2}{*}{ Tangibility } & $0.078 * * *$ & $0.079 * * *$ & $0.086^{* * *}$ & $0.087 * * *$ \\
\hline & $(5.24)$ & $(5.26)$ & $(3.28)$ & $(3.29)$ \\
\hline \multirow[t]{2}{*}{ Export firm } & $0.010 * * *$ & $0.008 * * *$ & $0.020^{*}$ & $0.019 *$ \\
\hline & $(3.42)$ & $(2.63)$ & $(1.85)$ & $(1.71)$ \\
\hline \multirow[t]{2}{*}{ GDP growth } & $0.003 * * *$ & $0.005^{* * *}$ & 0.001 & 0.003 \\
\hline & $(6.00)$ & $(8.73)$ & $(0.04)$ & $(1.21)$ \\
\hline \multirow[t]{2}{*}{ Stock returns } & $0.016 * * *$ & $0.027 * * *$ & $0.029^{*}$ & -0.002 \\
\hline & $(3.41)$ & $(5.58)$ & $(1.71)$ & $(-0.11)$ \\
\hline \multirow[t]{2}{*}{ Interbank rate } & $-0.004 * * *$ & $-0.004 * * *$ & 0.001 & 0.001 \\
\hline & $(-4.50)$ & $(-6.22)$ & $(0.21)$ & $(0.19)$ \\
\hline \multirow[t]{2}{*}{ Constant } & $0.625 * * *$ & $0.599 * * *$ & $0.864 * * *$ & $0.823 * * *$ \\
\hline & $(46.82)$ & $(46.53)$ & $(7.83)$ & $(7.58)$ \\
\hline Observations & 173,325 & 173,325 & 6,960 & 6,960 \\
\hline R-squared & 0.005 & 0.006 & 0.033 & 0.034 \\
\hline Number of firms & 24,169 & 24,169 & 1,937 & 1,937 \\
\hline
\end{tabular}

Notes: The table reports the results of equations (1) and (2). Domestic debt/Total debt is the ratio of proceeds from domestic currency bank borrowings over total debt. FX debt/Total debt is the ratio of proceeds from foreign currency borrowings over total debt. Regional financial cycle is the common factor in bank flows to the countries in the region. Global financial cycle is the common factor in bank flows to all countries in the BIS database. Firm-level controls are: Size as log of total real assets, Liquidity as ratio of quick assets to quick liabilities, Tangibility as ratio of net fixed assets to total real assets, Export firm is a dummy for firms with positive exports, and zero otherwise. Domestic controls are: GDP growth as real GDP growth, Stock returns as returns of the stock market index, Interbank rate as the money market interest rate. All equations include firm fixed effects. All control variables are lagged by one time period. Statistical significance is denoted at $1 \%(* * *), 5 \%(* *)$ and $10 \%(*)$. 
Table 4: Impact of regional factors on domestic credit market

\begin{tabular}{|c|c|c|c|c|c|c|}
\hline \multirow{3}{*}{$\begin{array}{l}\text { Dependent } \text { variable }= \\
\text { Regional factors }=\end{array}$} & \multirow{2}{*}{\multicolumn{3}{|c|}{$\begin{array}{l}(1) \\
\text { Domestic debt/Total debt }\end{array}$}} & \multirow{2}{*}{\multicolumn{3}{|c|}{$\begin{array}{c}(5) \\
\text { FX debt/Total debt }\end{array}$}} \\
\hline & & & & & & \\
\hline & $\begin{array}{l}\text { Regional } \\
\text { interbank } \\
\text { rate }\end{array}$ & $\begin{array}{c}\text { Regional } \\
\text { yield spread }\end{array}$ & $\begin{array}{l}\text { Regional } \\
\text { policy rate }\end{array}$ & $\begin{array}{l}\text { Regional } \\
\text { interbank } \\
\text { rate }\end{array}$ & $\begin{array}{c}\text { Regional } \\
\text { yield spread }\end{array}$ & $\begin{array}{l}\text { Regional } \\
\text { policy rate }\end{array}$ \\
\hline Global factors $=$ & $\begin{array}{l}\text { US interbank } \\
\text { rate }\end{array}$ & $\begin{array}{l}\text { US yield } \\
\text { spread }\end{array}$ & $\begin{array}{l}\text { US policy } \\
\text { rate }\end{array}$ & $\begin{array}{l}\text { US interbank } \\
\text { rate }\end{array}$ & $\begin{array}{l}\text { US yield } \\
\text { spread }\end{array}$ & $\begin{array}{l}\text { US policy } \\
\text { rate }\end{array}$ \\
\hline Regional factors & $\begin{array}{c}-0.016^{* * *} \\
(-10.40)\end{array}$ & $\begin{array}{c}-0.009 * * * \\
(-5.06)\end{array}$ & $\begin{array}{c}-0.028 * * * \\
(-9.00)\end{array}$ & $\begin{array}{l}0.011 \\
(1.40)\end{array}$ & $\begin{array}{l}0.001 \\
(0.29)\end{array}$ & $\begin{array}{l}-0.004 \\
(-0.44)\end{array}$ \\
\hline Global factors & $\begin{array}{c}-0.003 * * * \\
(-5.27)\end{array}$ & $\begin{array}{l}-0.002 \\
(-1.60)\end{array}$ & $\begin{array}{l}0.002 \\
(1.23)\end{array}$ & $\begin{array}{c}-0.008 * * * \\
(-3.59)\end{array}$ & $\begin{array}{c}-0.011 * * \\
(-1.98)\end{array}$ & $\begin{array}{c}-0.006^{*} \\
(-1.82)\end{array}$ \\
\hline Size & $\begin{array}{l}0.010^{* * *} \\
(6.43)\end{array}$ & $\begin{array}{l}0.010^{* * *} \\
(6.07)\end{array}$ & $\begin{array}{l}0.011 * * * \\
(6.97)\end{array}$ & $\begin{array}{c}0.043^{* * *} \\
(4.91)\end{array}$ & $\begin{array}{l}0.047 * * * \\
(5.29)\end{array}$ & $\begin{array}{c}0.043 * * * \\
(4.93)\end{array}$ \\
\hline Liquidity & $\begin{array}{l}0.001^{*} \\
(1.84)\end{array}$ & $\begin{array}{c}0.001^{*} \\
(1.87)\end{array}$ & $\begin{array}{c}0.001^{*} \\
(1.86)\end{array}$ & $\begin{array}{c}0.005 * * * \\
(2.90)\end{array}$ & $\begin{array}{c}0.005 * * * \\
(2.91)\end{array}$ & $\begin{array}{l}0.005^{* * *} \\
(2.89)\end{array}$ \\
\hline Tangibility & $\begin{array}{l}0.080 * * * \\
(5.25)\end{array}$ & $\begin{array}{l}0.079 * * * \\
(5.29)\end{array}$ & $\begin{array}{l}0.080 * * * \\
(5.26)\end{array}$ & $\begin{array}{l}0.075^{* * *} \\
(2.84)\end{array}$ & $\begin{array}{l}0.078 * * * \\
(2.94)\end{array}$ & $\begin{array}{l}0.074 * * * \\
(2.80)\end{array}$ \\
\hline Export firm & $\begin{array}{c}0.007 * * \\
(2.44)\end{array}$ & $\begin{array}{c}0.007 * * \\
(2.50)\end{array}$ & $\begin{array}{c}0.007 * * \\
(2.31)\end{array}$ & $\begin{array}{l}0.018 \\
(1.60)\end{array}$ & $\begin{array}{c}0.023^{* *} \\
(2.05)\end{array}$ & $\begin{array}{c}0.020^{*} \\
(1.81)\end{array}$ \\
\hline GDP growth & $\begin{array}{c}0.002 * * * \\
(4.96)\end{array}$ & $\begin{array}{c}0.007 * * * \\
(15.84)\end{array}$ & $\begin{array}{c}0.002 * * * \\
(3.95)\end{array}$ & $\begin{array}{l}0.001 \\
(0.90)\end{array}$ & $\begin{array}{l}0.002 \\
(0.91)\end{array}$ & $\begin{array}{c}0.006^{* * *} \\
(3.93)\end{array}$ \\
\hline Stock returns & $\begin{array}{c}0.074 * * * \\
(12.88)\end{array}$ & $\begin{array}{c}-0.026 * * * \\
(-5.28)\end{array}$ & $\begin{array}{c}0.085 * * * \\
(13.03)\end{array}$ & $\begin{array}{l}0.034 \\
(1.62)\end{array}$ & $\begin{array}{l}-0.023 \\
(-0.91)\end{array}$ & $\begin{array}{c}0.073 * * * \\
(2.80)\end{array}$ \\
\hline Interbank rate & $\begin{array}{c}-0.003 * * * \\
(-3.93)\end{array}$ & $\begin{array}{c}-0.002 * * * \\
(-2.96)\end{array}$ & $\begin{array}{c}-0.004 * * * \\
(-4.21)\end{array}$ & $\begin{array}{l}0.001 \\
(0.10)\end{array}$ & $\begin{array}{l}0.001 \\
(0.34)\end{array}$ & $\begin{array}{l}-0.003 \\
(-0.88)\end{array}$ \\
\hline Constant & $\begin{array}{c}0.596^{* * *} \\
(45.38)\end{array}$ & $\begin{array}{c}0.589 * * * \\
(45.63)\end{array}$ & $\begin{array}{c}0.592 * * * \\
(44.34)\end{array}$ & $\begin{array}{c}0.752^{* * *} \\
(9.55)\end{array}$ & $\begin{array}{c}0.798 * * * \\
(9.93)\end{array}$ & $\begin{array}{c}0.820 * * * \\
(10.27)\end{array}$ \\
\hline Observations & 173,325 & 173,325 & 173,325 & 6,960 & 6,960 & 6,960 \\
\hline $\mathrm{R}$-squared & 0.006 & 0.006 & 0.006 & 0.038 & 0.036 & 0.039 \\
\hline Number of firms & 24,169 & 24,169 & 24,169 & 1,937 & 1,937 & 1,937 \\
\hline
\end{tabular}

Notes: The table reports the results of equations (1) and (2) with regional and global factors. Domestic debt/Total debt is the ratio of proceeds from domestic currency bank borrowings over total debt. FX debt/Total debt is the ratio of proceeds from foreign currency borrowings over total debt. Regional factors are the average interbank rate, the average regional yield spread, as the difference between 10-year and 2-year government yields, and the average policy rate in the main lender countries in the region, as indicated in the columns. Global factors are the respective measures in the US. Firm-level controls are: Size as log of total real assets, Liquidity as ratio of quick assets to quick liabilities, Tangibility as ratio of net fixed assets to total real assets, Export firm is a dummy for firms with positive exports, and zero otherwise. Domestic controls are: GDP growth as real GDP growth, Stock returns as returns of the stock market index, Interbank rate as the money market interest rate. All equations include firm fixed effects. All control variables are lagged by one time period. Statistical significance is denoted at $1 \%(* * *), 5 \%(* *)$ and $10 \%(*)$. 
Table 5: Regional heterogeneity in bank funding conditions

\begin{tabular}{|c|c|c|c|c|c|c|}
\hline & (1) & $(2)$ & (3) & (4) & $(5)$ & (6) \\
\hline $\begin{array}{l}\text { Dependent } \\
\text { variable= }\end{array}$ & \multicolumn{3}{|c|}{ Domestic debt/Total debt } & \multicolumn{3}{|c|}{ FX debt/Total debt } \\
\hline Regional factors $=$ & $\begin{array}{c}\text { JP interbank } \\
\text { rate }\end{array}$ & $\begin{array}{c}\text { AUS } \\
\text { interbank rate }\end{array}$ & $\begin{array}{c}\text { SG interbank } \\
\text { rate }\end{array}$ & $\begin{array}{c}\text { JP interbank } \\
\text { rate }\end{array}$ & $\begin{array}{c}\text { AUS } \\
\text { interbank rate }\end{array}$ & $\begin{array}{c}S G \text { interbank } \\
\text { rate }\end{array}$ \\
\hline Global factors $=$ & $\begin{array}{c}\text { US interbank } \\
\text { rate }\end{array}$ & $\begin{array}{c}\text { US interbank } \\
\text { rate }\end{array}$ & $\begin{array}{c}\text { US interbank } \\
\text { rate }\end{array}$ & $\begin{array}{c}\text { US interbank } \\
\text { rate }\end{array}$ & $\begin{array}{c}\text { US interbank } \\
\text { rate }\end{array}$ & $\begin{array}{c}\text { US interbank } \\
\text { rate }\end{array}$ \\
\hline Regional factors & $\begin{array}{c}-0.048 * * * \\
(-8.88)\end{array}$ & $\begin{array}{c}-0.012 * * * \\
(-13.47)\end{array}$ & $\begin{array}{c}-0.009 * * * \\
(-7.09)\end{array}$ & $\begin{array}{l}0.009 \\
(0.39)\end{array}$ & $\begin{array}{l}-0.002 \\
(-0.54)\end{array}$ & $\begin{array}{l}-0.001 \\
(-0.12)\end{array}$ \\
\hline Global factors & $\begin{array}{c}-0.006 * * * \\
(-10.10)\end{array}$ & $\begin{array}{c}-0.007 * * * \\
(-10.35)\end{array}$ & $\begin{array}{c}-0.002 * * \\
(-2.50)\end{array}$ & $\begin{array}{c}-0.005 * * \\
(-1.97)\end{array}$ & $\begin{array}{c}-0.005^{*} \\
(-1.90)\end{array}$ & $\begin{array}{c}-0.005^{*} \\
(-1.88)\end{array}$ \\
\hline Size & $\begin{array}{c}0.009 * * * \\
(5.83)\end{array}$ & $\begin{array}{l}0.011 * * * \\
\quad(6.78)\end{array}$ & $\begin{array}{c}0.009 * * * \\
(5.75)\end{array}$ & $\begin{array}{c}0.044 * * * \\
(5.01)\end{array}$ & $\begin{array}{c}0.044 * * * \\
(5.01)\end{array}$ & $\begin{array}{c}0.044 * * * \\
(4.99)\end{array}$ \\
\hline Liquidity & $\begin{array}{l}0.001 * \\
(1.81)\end{array}$ & $\begin{array}{l}0.001 * \\
(1.85)\end{array}$ & $\begin{array}{l}0.001^{*} \\
(1.81)\end{array}$ & $\begin{array}{c}0.005^{* * * *} \\
(2.89)\end{array}$ & $\begin{array}{c}0.005 * * * \\
(2.89)\end{array}$ & $\begin{array}{c}0.005^{* * * *} \\
(2.89)\end{array}$ \\
\hline Tangibility & $\begin{array}{c}0.079 * * * \\
(5.24)\end{array}$ & $\begin{array}{c}0.079 * * * \\
(5.25)\end{array}$ & $\begin{array}{c}0.078 * * * \\
(5.26)\end{array}$ & $\begin{array}{c}0.074 * * * \\
(2.80)\end{array}$ & $\begin{array}{c}0.074 * * * \\
(2.81)\end{array}$ & $\begin{array}{c}0.074 * * * \\
(2.80)\end{array}$ \\
\hline Export firm & $\begin{array}{c}0.008 * * * \\
(2.61)\end{array}$ & $\begin{array}{c}0.007 * * \\
(2.40)\end{array}$ & $\begin{array}{c}0.008 * * * \\
(2.71)\end{array}$ & $\begin{array}{c}0.022 * * \\
(2.00)\end{array}$ & $\begin{array}{c}0.022 * * \\
(1.99)\end{array}$ & $\begin{array}{c}0.022 * * \\
(1.97)\end{array}$ \\
\hline GDP growth & $\begin{array}{c}0.003 * * * \\
(6.46)\end{array}$ & $\begin{array}{c}0.002 * * * \\
(3.55)\end{array}$ & $\begin{array}{c}0.003 * * * \\
(5.85)\end{array}$ & $\begin{array}{c}0.007 * * * \\
(4.10)\end{array}$ & $\begin{array}{c}0.007 * * * \\
(3.90)\end{array}$ & $\begin{array}{c}0.007 * * * \\
(4.39)\end{array}$ \\
\hline Stock returns & $\begin{array}{c}0.071 * * * \\
(13.29)\end{array}$ & $\begin{array}{c}0.092 * * * \\
(14.18)\end{array}$ & $\begin{array}{c}0.050 * * * \\
(11.12)\end{array}$ & $\begin{array}{c}0.057 * * * \\
(3.12)\end{array}$ & $\begin{array}{c}0.066^{* * *} * \\
(2.62)\end{array}$ & $\begin{array}{c}0.060^{* * * *} \\
(3.16)\end{array}$ \\
\hline Interbank rate & $\begin{array}{c}-0.002 * * \\
(-2.33)\end{array}$ & $\begin{array}{c}-0.005 * * * \\
(-5.80)\end{array}$ & $\begin{array}{c}-0.002 * * * \\
(-2.67)\end{array}$ & $\begin{array}{l}-0.003 \\
(-1.00)\end{array}$ & $\begin{array}{l}-0.004 \\
(-0.98)\end{array}$ & $\begin{array}{l}-0.003 \\
(-0.96)\end{array}$ \\
\hline Constant & $\begin{array}{c}0.590 * * * \\
(45.00)\end{array}$ & $\begin{array}{c}0.605 * * * \\
(45.82)\end{array}$ & $\begin{array}{c}0.598 * * * \\
(45.65)\end{array}$ & $\begin{array}{c}0.838 * * * \\
(10.31)\end{array}$ & $\begin{array}{c}0.840 * * * \\
(10.19)\end{array}$ & $\begin{array}{c}0.835^{* * *} \\
(10.26)\end{array}$ \\
\hline Observations & 173,325 & 173,325 & 173,325 & 6,960 & 6,960 & 6,960 \\
\hline R-squared & 0.006 & 0.006 & 0.005 & 0.039 & 0.039 & 0.039 \\
\hline Number of firms & 24,169 & 24,169 & 24,169 & 1,937 & 1,937 & 1,937 \\
\hline
\end{tabular}

Notes: The table reports the results of equations (1) and (2) with regional and global factors, where regional factors are the factors from Japan (JP), Australia (AUS) and Singapore (SG), as indicated in the columns. Domestic debt/Total debt is the ratio of proceeds from domestic currency bank borrowings over total debt. $F X$ debt/Total debt is the ratio of proceeds from foreign currency borrowings over total debt. Regional factors are the interbank rates. Global factors are the respective US-based measures. Firmlevel controls are: Size as log of total real assets, Liquidity as ratio of quick assets to quick liabilities, Tangibility as ratio of net fixed assets to total real assets, Export firm is a dummy for firms with positive exports, and zero otherwise. Domestic controls are: GDP growth as real GDP growth, Stock returns as returns of the stock market index, Interbank rate as the money market interest rate. All equations include firm fixed effects. All control variables are lagged by one time period. Statistical significance is denoted at $1 \%(* * *), 5 \%(* *)$ and $10 \%(*)$. 
Table 6: Regional heterogeneity in monetary policy

\begin{tabular}{|c|c|c|c|c|c|c|c|c|c|c|c|c|c|c|}
\hline \multirow[b]{2}{*}{$\begin{array}{l}\text { Dependent } \\
\text { variable= }\end{array}$} & (1) & (2) & (3) & $(4)$ & $(5)$ & (6) & (7) & $(8)$ & (9) & $(10)$ & $(11)$ & $(12)$ & (13) & (14) \\
\hline & \multicolumn{7}{|c|}{ Domestic debt/Total debt } & \multicolumn{7}{|c|}{ FX debt/Total debt } \\
\hline Regional factors $=$ & $\begin{array}{l}\text { JP yield } \\
\text { spread }\end{array}$ & $\begin{array}{l}\text { AUS yield } \\
\text { spread }\end{array}$ & $\begin{array}{l}\text { SG yield } \\
\text { spread }\end{array}$ & $\begin{array}{l}\text { JP policy } \\
\text { rate }\end{array}$ & $\begin{array}{l}\text { AUS policy } \\
\text { rate }\end{array}$ & $\begin{array}{c}S G \text { policy } \\
\text { rate }\end{array}$ & $\begin{array}{l}\text { JP monetary } \\
\text { uncertainty }\end{array}$ & $\begin{array}{l}\text { JP yield } \\
\text { spread }\end{array}$ & $\begin{array}{l}\text { AUS yield } \\
\text { spread }\end{array}$ & $\begin{array}{l}\text { SG yield } \\
\text { spread }\end{array}$ & $\begin{array}{l}J P \text { policy } \\
\text { rate }\end{array}$ & $\begin{array}{l}\text { AUS policy } \\
\text { rate }\end{array}$ & $\begin{array}{l}S G \text { policy } \\
\text { rate }\end{array}$ & $\begin{array}{c}\text { JP monetary } \\
\text { uncertainty }\end{array}$ \\
\hline Global factors $=$ & $\begin{array}{l}\text { US yield } \\
\text { spread }\end{array}$ & $\begin{array}{l}\text { US yield } \\
\text { spread }\end{array}$ & $\begin{array}{l}\text { US yield } \\
\text { spread }\end{array}$ & $\begin{array}{l}\text { US policy } \\
\text { rate }\end{array}$ & $\begin{array}{l}\text { US policy } \\
\text { rate }\end{array}$ & $\begin{array}{l}\text { US policy } \\
\text { rate }\end{array}$ & $\begin{array}{l}\text { US monetary } \\
\text { uncertainty }\end{array}$ & $\begin{array}{l}\text { US yield } \\
\text { spread }\end{array}$ & $\begin{array}{l}\text { US yield } \\
\text { spread }\end{array}$ & $\begin{array}{l}\text { US yield } \\
\text { spread }\end{array}$ & $\begin{array}{l}\text { US policy } \\
\text { rate }\end{array}$ & $\begin{array}{l}\text { US policy } \\
\text { rate }\end{array}$ & $\begin{array}{l}\text { US policy } \\
\text { rate }\end{array}$ & $\begin{array}{l}\text { US monetary } \\
\text { uncertainty }\end{array}$ \\
\hline Regional factors & $\begin{array}{c}-0.014 * * * \\
(-5.42)\end{array}$ & $\begin{array}{c}-0.002 * * * \\
(-7.87)\end{array}$ & $\begin{array}{c}-0.001 * * \\
(-2.57)\end{array}$ & $\begin{array}{c}-0.037 * * * \\
(-6.37)\end{array}$ & $\begin{array}{c}-0.010 * * * \\
(-12.71)\end{array}$ & $\begin{array}{c}-0.018 * * * \\
(-7.34)\end{array}$ & $\begin{array}{c}-0.015 * * * \\
(-4.82)\end{array}$ & $\begin{array}{l}-0.005 \\
(-0.43)\end{array}$ & $\begin{array}{l}-0.001 \\
(-0.56)\end{array}$ & $\begin{array}{l}0.002 \\
(1.58)\end{array}$ & $\begin{array}{l}0.001 \\
(0.01)\end{array}$ & $\begin{array}{l}-0.002 \\
(-0.73)\end{array}$ & $\begin{array}{c}0.017^{*} \\
(1.68)\end{array}$ & $\begin{array}{c}-0.053^{* * *} \\
(-3.99)\end{array}$ \\
\hline Global factors & $\begin{array}{l}-0.001 \\
(-1.33)\end{array}$ & $\begin{array}{l}0.002 \\
(1.25)\end{array}$ & $\begin{array}{l}0.004 \\
(1.52)\end{array}$ & $\begin{array}{c}-0.008 * * * \\
(-9.28)\end{array}$ & $\begin{array}{c}-0.006^{* * *} \\
(-9.89)\end{array}$ & $\begin{array}{l}0.001 \\
(0.70)\end{array}$ & $\begin{array}{c}-0.026^{* * *} \\
(-8.42)\end{array}$ & $\begin{array}{c}-0.009 * * \\
(-2.02)\end{array}$ & $\begin{array}{c}-0.010^{* *} \\
(-2.06)\end{array}$ & $\begin{array}{c}-0.023 * * \\
(-2.07)\end{array}$ & $\begin{array}{c}-0.010 * * \\
(-2.20)\end{array}$ & $\begin{array}{c}-0.007^{*} \\
(-1.87)\end{array}$ & $\begin{array}{c}-0.021 * * * \\
(-3.60)\end{array}$ & $\begin{array}{c}-0.048 * * * \\
(-3.55)\end{array}$ \\
\hline Size & $\begin{array}{c}0.006 * * * \\
(4.17)\end{array}$ & $\begin{array}{c}0.011 * * * \\
(7.15)\end{array}$ & $\begin{array}{c}0.012 * * * \\
(6.21)\end{array}$ & $\begin{array}{c}0.009 * * * \\
(6.02)\end{array}$ & $\begin{array}{l}0.010 * * * \\
(6.15)\end{array}$ & $\begin{array}{l}-0.001 \\
(-0.75)\end{array}$ & $\begin{array}{c}0.013 * * * \\
(7.81)\end{array}$ & $\begin{array}{c}0.048 * * * \\
(5.38)\end{array}$ & $\begin{array}{c}0.045 * * * \\
(5.01)\end{array}$ & $\begin{array}{c}0.045^{* * *} * \\
(5.09)\end{array}$ & $\begin{array}{c}0.043 * * * \\
(4.83)\end{array}$ & $\begin{array}{c}0.043 * * * \\
(4.93)\end{array}$ & $\begin{array}{c}0.043 * * * \\
(4.85)\end{array}$ & $\begin{array}{c}0.037 * * * \\
(4.08)\end{array}$ \\
\hline Liquidity & $\begin{array}{c}0.001^{*} \\
(1.79)\end{array}$ & $\begin{array}{c}0.001 * \\
(1.91)\end{array}$ & $\begin{array}{c}0.001 * \\
(1.79)\end{array}$ & $\begin{array}{c}0.001^{*} \\
(1.83)\end{array}$ & $\begin{array}{c}0.001^{*} \\
(1.83)\end{array}$ & $\begin{array}{c}0.001^{*} \\
(1.76)\end{array}$ & $\begin{array}{c}0.001^{*} \\
(1.91)\end{array}$ & $\begin{array}{c}0.005 * * * \\
(2.90)\end{array}$ & $\begin{array}{c}0.005 * * * \\
(2.89)\end{array}$ & $\begin{array}{c}0.005 * * * \\
(2.92)\end{array}$ & $\begin{array}{c}0.005 * * * \\
(2.85)\end{array}$ & $\begin{array}{c}0.005 * * * \\
(2.89)\end{array}$ & $\begin{array}{l}0.004 * * * \\
(2.66)\end{array}$ & $\begin{array}{l}0.005 * * * \\
(2.88)\end{array}$ \\
\hline Tangibility & $\begin{array}{c}0.078 * * * \\
(5.24)\end{array}$ & $\begin{array}{c}0.080 * * * \\
(5.31)\end{array}$ & $\begin{array}{l}0.074 * * * \\
\quad(5.16)\end{array}$ & $\begin{array}{l}0.079 * * * \\
\quad(5.24)\end{array}$ & $\begin{array}{l}0.079 * * * \\
\quad(5.25)\end{array}$ & $\begin{array}{c}0.063 * * * \\
(4.37)\end{array}$ & $\begin{array}{l}0.080^{* * * *} \\
\quad(5.29)\end{array}$ & $\begin{array}{c}0.076^{* * * *} \\
(2.88)\end{array}$ & $\begin{array}{c}0.077 * * * \\
(2.95)\end{array}$ & $\begin{array}{c}0.080 * * * \\
(3.03)\end{array}$ & $\begin{array}{l}0.072 * * * \\
\quad(2.71)\end{array}$ & $\begin{array}{c}0.073 * * * \\
(2.78)\end{array}$ & $\begin{array}{c}0.078 * * * \\
(3.19)\end{array}$ & $\begin{array}{l}0.072 * * * \\
(2.73)\end{array}$ \\
\hline Export firm & $\begin{array}{c}0.010 * * * \\
(3.45)\end{array}$ & $\begin{array}{c}0.007 * * \\
(2.33)\end{array}$ & $\begin{array}{l}0.010 * * * \\
(3.38)\end{array}$ & $\begin{array}{l}0.008 * * * \\
(2.72)\end{array}$ & $\begin{array}{l}0.008 * * * \\
(2.78)\end{array}$ & $\begin{array}{l}0.004 \\
(1.36)\end{array}$ & $\begin{array}{c}0.006 * * \\
(2.02)\end{array}$ & $\begin{array}{c}0.024 * * \\
(2.19)\end{array}$ & $\begin{array}{c}0.022 * * \\
(1.99)\end{array}$ & $\begin{array}{c}0.023 * * \\
(2.05)\end{array}$ & $\begin{array}{l}0.015 \\
(1.34)\end{array}$ & $\begin{array}{l}0.020^{*} \\
(1.84)\end{array}$ & $\begin{array}{l}0.017 \\
(1.55)\end{array}$ & $\begin{array}{l}0.017 \\
(1.53)\end{array}$ \\
\hline GDP growth & $\begin{array}{c}0.004 * * * \\
(11.02)\end{array}$ & $\begin{array}{c}0.004 * * * \\
(12.50)\end{array}$ & $\begin{array}{c}0.004^{* * *} \\
(10.15)\end{array}$ & $\begin{array}{c}0.002 * * * \\
\quad(4.76)\end{array}$ & $\begin{array}{l}0.001 \\
(0.77)\end{array}$ & $\begin{array}{l}-0.001 \\
(-0.62)\end{array}$ & $\begin{array}{c}0.002 * * * \\
\quad(7.32)\end{array}$ & $\begin{array}{c}0.003 * * \\
(2.11)\end{array}$ & $\begin{array}{l}0.001 \\
(0.91)\end{array}$ & $\begin{array}{l}0.001 \\
(0.07)\end{array}$ & $\begin{array}{l}0.002 \\
(1.27)\end{array}$ & $\begin{array}{c}0.007 * * * \\
\quad(3.60)\end{array}$ & $\begin{array}{c}0.005 * * * \\
\quad(3.23)\end{array}$ & $\begin{array}{c}0.003 * * \\
(2.15)\end{array}$ \\
\hline Stock returns & $\begin{array}{l}0.003 \\
(0.87)\end{array}$ & $\begin{array}{c}0.028 * * * \\
(9.02)\end{array}$ & $\begin{array}{l}0.002 \\
(0.43)\end{array}$ & $\begin{array}{c}0.058 * * * \\
(10.61)\end{array}$ & $\begin{array}{c}0.072 * * * \\
(13.05)\end{array}$ & $\begin{array}{c}0.050^{* * *} \\
(9.12)\end{array}$ & $\begin{array}{c}0.026 * * * \\
(6.57)\end{array}$ & $\begin{array}{l}-0.001 \\
(-0.09)\end{array}$ & $\begin{array}{l}0.015 \\
(0.93)\end{array}$ & $\begin{array}{l}0.014 \\
(0.99)\end{array}$ & $\begin{array}{c}0.036^{* *} \\
(2.21)\end{array}$ & $\begin{array}{c}0.076^{* * *} \\
(3.05)\end{array}$ & $\begin{array}{l}0.029 \\
(1.46)\end{array}$ & $\begin{array}{l}-0.006 \\
(-0.39)\end{array}$ \\
\hline Interbank rate & $\begin{array}{c}-0.003^{* * *} \\
(-3.40)\end{array}$ & $\begin{array}{c}-0.002^{* * *} \\
(-3.42)\end{array}$ & $\begin{array}{c}-0.002 * * * \\
(-3.16)\end{array}$ & $\begin{array}{c}-0.003^{* * *} \\
(-3.47)\end{array}$ & $\begin{array}{c}-0.005^{* * *} \\
(-6.07)\end{array}$ & $\begin{array}{c}-0.004 * * * \\
(-5.04)\end{array}$ & $\begin{array}{c}-0.003 * * * \\
(-4.29)\end{array}$ & $\begin{array}{l}-0.001 \\
(-0.10)\end{array}$ & $\begin{array}{l}0.004 \\
(1.29)\end{array}$ & $\begin{array}{l}0.001 \\
(0.02)\end{array}$ & $\begin{array}{l}0.002 \\
(0.69)\end{array}$ & $\begin{array}{l}-0.003 \\
(-0.95)\end{array}$ & $\begin{array}{l}-0.002 \\
(-0.80)\end{array}$ & $\begin{array}{l}0.001 \\
(0.37)\end{array}$ \\
\hline Constant & $\begin{array}{c}0.615^{* * * *} \\
(48.08)\end{array}$ & $\begin{array}{c}0.583 * * * \\
(45.78)\end{array}$ & $\begin{array}{c}0.585^{* * *} \\
(39.77)\end{array}$ & $\begin{array}{c}0.603 * * * \\
(46.98)\end{array}$ & $\begin{array}{c}0.626^{* * *} \\
(47.33)\end{array}$ & $\begin{array}{c}0.702 * * * \\
(50.82)\end{array}$ & $\begin{array}{c}0.782 * * * \\
(27.31)\end{array}$ & $\begin{array}{c}0.836^{* * *} \\
(10.27)\end{array}$ & $\begin{array}{c}0.757 * * * \\
\quad(9.09)\end{array}$ & $\begin{array}{c}0.785 * * * \\
\quad(9.93)\end{array}$ & $\begin{array}{c}0.727 * * * \\
\quad(8.63)\end{array}$ & $\begin{array}{c}0.827 * * * \\
(10.07)\end{array}$ & $\begin{array}{c}0.822 * * * \\
(10.39)\end{array}$ & $\begin{array}{c}1.200^{* * * *} \\
(8.85)\end{array}$ \\
\hline Observations & 173,325 & 173,325 & 173,319 & 173,325 & 173,325 & 173,325 & 173,325 & 6,960 & 6,960 & 6,960 & 6,960 & 6,960 & 6,960 & 6,960 \\
\hline R-squared & 0.004 & 0.006 & 0.005 & 0.006 & 0.006 & 0.006 & 0.006 & 0.039 & 0.039 & 0.039 & 0.039 & 0.039 & 0.039 & 0.040 \\
\hline Number of firms & 24,169 & 24,169 & 24,168 & 24,169 & 24,169 & 24,169 & 24,169 & 1,937 & 1,937 & 1,937 & 1,937 & 1,937 & 1,937 & 1,921 \\
\hline
\end{tabular}

Notes: The table reports the results of equations (1) and (2) with regional and global factors, where regional factors are the factors from Japan (JP), Australia (AUS) and Singapore (SG), as indicated in the columns. Domestic debt/Total debt is the ratio of proceeds from domestic currency bank borrowings over total debt. FX debt/Total debt is the ratio of proceeds from foreign currency borrowings over total debt. Regional factors are the yield spread, as the difference between 10-year and 2-year government yields, and policy rate. JP monetary uncertainty is from Arbatli et al. (2019). Global factors are the respective measures in the US. Firm-level controls are: Size as log of total real assets, Liquidity as ratio of quick assets to quick liabilities, Tangibility as ratio of net fixed assets to total real assets, Export firm is a dummy for firms with positive exports, and zero otherwise. Domestic controls are: GDP growth as real GDP growth, Stock returns as returns of the stock market index, Interbank rate as the money market interest rate. All equations include firm fixed effects. All control variables are lagged by one time period. Statistical significance is denoted at $1 \%(* * *), 5 \%(* *)$ and $10 \%(*)$. 
Table 7: Accounting for firm-level transparency

\begin{tabular}{|c|c|c|c|c|c|c|c|c|c|c|c|c|c|c|c|c|}
\hline \multirow{3}{*}{$\begin{array}{l}\text { Dependent } \\
\text { variable= }\end{array}$} & $(1)$ & $(2)$ & $(3)$ & $(4)$ & $(5)$ & $(6)$ & $(7)$ & $(8)$ & $(9)$ & $(10)$ & $(11)$ & $(12)$ & $(13)$ & $(14)$ & $(15)$ & $(16)$ \\
\hline & \multicolumn{8}{|c|}{ Domestic debt/Total debt } & \multicolumn{8}{|c|}{ FX debt/Total debt } \\
\hline & $\begin{array}{l}\text { Larger } \\
\text { firms }\end{array}$ & $\begin{array}{l}\text { Smaller } \\
\text { firms }\end{array}$ & Audit firms & $\begin{array}{l}\text { Non- } \\
\text { audit } \\
\text { firms }\end{array}$ & $\begin{array}{c}\text { High } \\
\text { collateral }\end{array}$ & $\begin{array}{c}\text { Low } \\
\text { collateral }\end{array}$ & $\begin{array}{c}\text { Multiple } \\
\text { bankers }\end{array}$ & $\begin{array}{l}\text { Single } \\
\text { banker }\end{array}$ & $\begin{array}{l}\text { Larger } \\
\text { firms }\end{array}$ & $\begin{array}{c}\text { Smaller } \\
\text { firms }\end{array}$ & Audit firms & $\begin{array}{l}\text { Non- } \\
\text { audit } \\
\text { firms }\end{array}$ & $\begin{array}{c}\text { High } \\
\text { collateral }\end{array}$ & $\begin{array}{c}\text { Low } \\
\text { collateral }\end{array}$ & $\begin{array}{c}\text { Multiple } \\
\text { bankers }\end{array}$ & $\begin{array}{l}\text { Single } \\
\text { banker }\end{array}$ \\
\hline $\begin{array}{l}\text { Regional } \\
\text { financial } \\
\text { cycle }\end{array}$ & $\begin{array}{c}0.027 * * * \\
(7.44)\end{array}$ & $\begin{array}{l}-0.001 \\
(-0.26)\end{array}$ & $\begin{array}{c}0.023 * * * \\
(6.97)\end{array}$ & $\begin{array}{l}0.008 \\
(1.20)\end{array}$ & $\begin{array}{c}0.026^{* * * *} \\
(7.02)\end{array}$ & $\begin{array}{l}0.007 \\
(1.48)\end{array}$ & $\begin{array}{c}0.036^{* * *} \\
(4.88)\end{array}$ & $\begin{array}{c}0.018 \\
(1.57)\end{array}$ & $\begin{array}{l}-0.020 \\
(-1.55)\end{array}$ & $\begin{array}{l}-0.027 \\
(-0.90)\end{array}$ & $\begin{array}{l}-0.019 \\
(-1.41)\end{array}$ & $\begin{array}{l}0.053 \\
(0.89)\end{array}$ & $\begin{array}{l}-0.014 \\
(-1.10)\end{array}$ & $\begin{array}{l}-0.003 \\
(-0.09)\end{array}$ & $\begin{array}{l}-0.002 \\
(-0.08)\end{array}$ & $\begin{array}{l}-0.044 \\
(-0.85)\end{array}$ \\
\hline $\begin{array}{l}\text { Global } \\
\text { financial } \\
\text { cycle }\end{array}$ & $\begin{array}{l}-0.043 \\
(-1.32)\end{array}$ & $\begin{array}{l}0.011 \\
(0.23)\end{array}$ & $\begin{array}{l}-0.023 \\
(-0.71)\end{array}$ & $\begin{array}{l}0.071 \\
(1.34)\end{array}$ & $\begin{array}{l}0.005 \\
(0.14)\end{array}$ & $\begin{array}{l}0.044 \\
(0.99)\end{array}$ & $\begin{array}{l}-0.082 \\
(-1.38)\end{array}$ & $\begin{array}{l}-0.100 \\
(-1.21)\end{array}$ & $\begin{array}{c}0.192 * * \\
(2.34)\end{array}$ & $\begin{array}{l}0.300 \\
(0.99)\end{array}$ & $\begin{array}{c}0.163^{* *} \\
(2.06)\end{array}$ & $\begin{array}{l}0.057 \\
(0.20)\end{array}$ & $\begin{array}{c}0.190^{*} \\
(1.74)\end{array}$ & $\begin{array}{l}0.182 \\
(1.20)\end{array}$ & $\begin{array}{c}0.222 * * \\
(2.05)\end{array}$ & $\begin{array}{l}-0.514 \\
(-1.58)\end{array}$ \\
\hline Size & $\begin{array}{c}0.008 * * * \\
(4.23)\end{array}$ & $\begin{array}{c}0.010 * * * \\
(3.09)\end{array}$ & $\begin{array}{c}0.010 * * * \\
(4.89)\end{array}$ & $\begin{array}{c}0.009 * * * \\
(2.97)\end{array}$ & $\begin{array}{c}0.018^{* * *} \\
(7.70)\end{array}$ & $\begin{array}{c}0.007 * * * \\
(2.69)\end{array}$ & $\begin{array}{c}0.017 * * * \\
(4.92)\end{array}$ & $\begin{array}{c}0.020 * * * \\
(3.03)\end{array}$ & $\begin{array}{c}0.047 * * * \\
(4.93)\end{array}$ & $\begin{array}{l}0.001 \\
(0.06)\end{array}$ & $\begin{array}{c}0.045 * * * \\
(4.48)\end{array}$ & $\begin{array}{l}0.023 \\
(1.35)\end{array}$ & $\begin{array}{c}0.044 * * * \\
(3.63)\end{array}$ & $\begin{array}{c}0.037 * * * \\
(2.68)\end{array}$ & $\begin{array}{c}0.054 * * * \\
(3.46)\end{array}$ & $\begin{array}{l}0.021 \\
(0.46)\end{array}$ \\
\hline Liquidity & $\begin{array}{l}0.001 \\
(1.30)\end{array}$ & $\begin{array}{c}0.001^{*} \\
(1.79)\end{array}$ & $\begin{array}{c}0.001 * * \\
(2.56)\end{array}$ & $\begin{array}{l}0.001 \\
(0.65)\end{array}$ & $\begin{array}{l}0.001 \\
(1.08)\end{array}$ & $\begin{array}{l}0.001 \\
(0.86)\end{array}$ & $\begin{array}{l}0.001 \\
(1.57)\end{array}$ & $\begin{array}{l}0.001 \\
(0.40)\end{array}$ & $\begin{array}{c}0.005 * * * \\
(2.81)\end{array}$ & $\begin{array}{l}0.002 \\
(0.29)\end{array}$ & $\begin{array}{c}0.005^{* *} \\
(2.16)\end{array}$ & $\begin{array}{l}0.001 \\
(0.91)\end{array}$ & $\begin{array}{l}0.004 \\
(1.41)\end{array}$ & $\begin{array}{c}0.008^{* *} \\
(2.16)\end{array}$ & $\begin{array}{c}0.032 * * * \\
(5.68)\end{array}$ & $\begin{array}{l}0.027 \\
(1.51)\end{array}$ \\
\hline Tangibility & $\begin{array}{c}0.106^{* * *} \\
(12.78)\end{array}$ & $\begin{array}{l}0.042 * \\
(1.94)\end{array}$ & $\begin{array}{c}0.100^{* * *} \\
(11.03)\end{array}$ & $\begin{array}{c}0.028^{*} \\
(1.76)\end{array}$ & $\begin{array}{c}0.104 * * * \\
(13.16)\end{array}$ & $\begin{array}{l}0.006 \\
(0.71)\end{array}$ & $\begin{array}{c}0.068 * * * \\
(2.60)\end{array}$ & $\begin{array}{c}0.124 * * * \\
(4.53)\end{array}$ & $\begin{array}{c}0.079 * * * \\
(2.83)\end{array}$ & $\begin{array}{l}0.092 \\
(1.39)\end{array}$ & $\begin{array}{c}0.088 * * * \\
(2.90)\end{array}$ & $\begin{array}{l}0.014 \\
(0.22)\end{array}$ & $\begin{array}{c}0.094 * * * \\
\quad(3.60)\end{array}$ & $\begin{array}{l}0.090 \\
(1.38)\end{array}$ & $\begin{array}{l}0.055 \\
(0.86)\end{array}$ & $\begin{array}{c}0.221^{*} \\
(1.69)\end{array}$ \\
\hline Export firm & $\begin{array}{l}0.002 \\
(0.62)\end{array}$ & $\begin{array}{c}0.021 * * * \\
(3.53)\end{array}$ & $\begin{array}{l}0.005 \\
(1.49)\end{array}$ & $\begin{array}{c}0.019 * * * \\
(2.65)\end{array}$ & $\begin{array}{l}0.006^{*} \\
(1.65)\end{array}$ & $\begin{array}{c}0.008^{*} \\
(1.79)\end{array}$ & $\begin{array}{c}0.016^{* * * *} \\
\quad(2.68)\end{array}$ & $\begin{array}{c}0.017^{*} \\
(1.82)\end{array}$ & $\begin{array}{c}0.023 * * \\
(2.00)\end{array}$ & $\begin{array}{l}0.021 \\
(0.44)\end{array}$ & $\begin{array}{c}0.030 * * \\
(2.51)\end{array}$ & $\begin{array}{l}0.017 \\
(0.40)\end{array}$ & $\begin{array}{l}0.016 \\
(1.27)\end{array}$ & $\begin{array}{c}0.059 * * \\
(2.27)\end{array}$ & $\begin{array}{c}0.030^{*} \\
(1.89)\end{array}$ & $\begin{array}{l}-0.136 \\
(-1.38)\end{array}$ \\
\hline GDP growth & $\begin{array}{c}0.005 * * * \\
(7.53)\end{array}$ & $\begin{array}{c}0.002^{* *} \\
(2.10)\end{array}$ & $\begin{array}{c}0.005^{* * *} \\
(8.04)\end{array}$ & $\begin{array}{c}0.005^{* * *} \\
(4.39)\end{array}$ & $\begin{array}{c}0.006 * * * \\
(8.32)\end{array}$ & $\begin{array}{c}0.004 * * * \\
(4.76)\end{array}$ & $\begin{array}{c}0.005 * * * \\
(4.00)\end{array}$ & $\begin{array}{l}0.001 \\
(0.59)\end{array}$ & $\begin{array}{c}0.007 * * * \\
(4.14)\end{array}$ & $\begin{array}{l}0.005 \\
(1.09)\end{array}$ & $\begin{array}{c}0.008^{* * *} \\
(4.06)\end{array}$ & $\begin{array}{l}0.006 \\
(0.83)\end{array}$ & $\begin{array}{c}0.005 * * * \\
(2.77)\end{array}$ & $\begin{array}{c}0.013 * * * \\
(2.92)\end{array}$ & $\begin{array}{c}0.007 * * * \\
(2.98)\end{array}$ & $\begin{array}{l}0.001 \\
(0.12)\end{array}$ \\
\hline Stock returns & $\begin{array}{c}0.033 * * * \\
(5.77)\end{array}$ & $\begin{array}{c}0.015^{*} \\
(1.77)\end{array}$ & $\begin{array}{c}0.028 * * * \\
(5.05)\end{array}$ & $\begin{array}{l}0.014 \\
(1.46)\end{array}$ & $\begin{array}{c}0.030 * * * \\
(5.01)\end{array}$ & $\begin{array}{c}0.015^{*} \\
(1.87)\end{array}$ & $\begin{array}{c}0.032 * * * \\
(2.82)\end{array}$ & $\begin{array}{c}0.036^{* *} \\
(2.17)\end{array}$ & $\begin{array}{c}0.052 * * \\
(2.50)\end{array}$ & $\begin{array}{c}0.146^{* *} \\
(2.03)\end{array}$ & $\begin{array}{c}0.066^{* * *} * \\
(3.02)\end{array}$ & $\begin{array}{l}0.028 \\
(0.30)\end{array}$ & $\begin{array}{l}0.001 \\
(0.01)\end{array}$ & $\begin{array}{c}0.117 * * * \\
(2.63)\end{array}$ & $\begin{array}{l}0.018 \\
(0.57)\end{array}$ & $\begin{array}{c}0.134 * \\
(1.77)\end{array}$ \\
\hline $\begin{array}{l}\text { Interbank } \\
\text { rate }\end{array}$ & $\begin{array}{c}-0.005 * * * \\
(-5.91)\end{array}$ & $\begin{array}{l}-0.000 \\
(-0.30)\end{array}$ & $\begin{array}{c}-0.004 * * * \\
(-5.45)\end{array}$ & $\begin{array}{c}-0.004 * * \\
(-2.42)\end{array}$ & $\begin{array}{c}-0.006^{* * *} \\
(-6.20)\end{array}$ & $\begin{array}{c}-0.004 * * * \\
(-3.28)\end{array}$ & $\begin{array}{c}-0.007 * * * \\
(-4.14)\end{array}$ & $\begin{array}{l}-0.003 \\
(-1.17)\end{array}$ & $\begin{array}{l}-0.001 \\
(-0.26)\end{array}$ & $\begin{array}{c}-0.030 * \\
(-1.90)\end{array}$ & $\begin{array}{l}-0.003 \\
(-0.93)\end{array}$ & $\begin{array}{l}0.005 \\
(0.44)\end{array}$ & $\begin{array}{l}-0.001 \\
(-0.10)\end{array}$ & $\begin{array}{l}-0.001 \\
(-0.08)\end{array}$ & $\begin{array}{l}-0.001 \\
(-0.03)\end{array}$ & $\begin{array}{l}0.011 \\
(0.73)\end{array}$ \\
\hline Constant & $\begin{array}{c}0.617 * * * \\
(40.02)\end{array}$ & $\begin{array}{c}0.588 * * * \\
(28.98)\end{array}$ & $\begin{array}{c}0.599 * * * \\
(37.24)\end{array}$ & $\begin{array}{c}0.585 * * * \\
(28.74)\end{array}$ & $\begin{array}{c}0.561 * * * \\
(33.10)\end{array}$ & $\begin{array}{c}0.609 * * * \\
(33.19)\end{array}$ & $\begin{array}{c}0.537 * * * \\
(18.13)\end{array}$ & $\begin{array}{c}0.588 * * * \\
(13.67)\end{array}$ & $\begin{array}{c}0.857 * * * \\
(9.24)\end{array}$ & $\begin{array}{c}0.422^{* *} \\
(2.48)\end{array}$ & $\begin{array}{c}0.858 * * * \\
(9.05)\end{array}$ & $\begin{array}{c}0.603 * * * \\
(4.93)\end{array}$ & $\begin{array}{c}0.827 * * * \\
(7.66)\end{array}$ & $\begin{array}{c}0.758 * * * \\
(5.90)\end{array}$ & $\begin{array}{c}0.829 * * * \\
(5.35)\end{array}$ & $\begin{array}{l}0.064 \\
(0.16)\end{array}$ \\
\hline Observations & 117,047 & 56,278 & 125,849 & 47,476 & 99,376 & 73,949 & 44,619 & 20,811 & 6,558 & 402 & 6,425 & 535 & 4,911 & 2,049 & 3,015 & 328 \\
\hline R-squared & 0.008 & 0.003 & 0.007 & 0.004 & 0.010 & 0.002 & 0.010 & 0.011 & 0.041 & 0.061 & 0.041 & 0.032 & 0.028 & 0.058 & 0.083 & 0.115 \\
\hline $\begin{array}{l}\text { Number of } \\
\text { firms }\end{array}$ & 16,173 & 12,705 & 19,266 & 13,671 & 16,372 & 15,569 & 9,235 & 6,019 & 1,813 & 172 & 1,810 & 326 & 1,467 & 781 & 796 & 155 \\
\hline
\end{tabular}

Notes: The table reports the results of equations (1) and (2). Domestic debt/Total debt is the ratio of proceeds from domestic currency bank borrowings over total debt. FX debt/Total debt is the ratio of proceeds from foreign currency borrowings over total debt. Regional financial cycle is the common factor in bank flows to the countries in the region. Global financial cycle is the common factor in bank flows to all countries in the BIS database. All equations include firm fixed effects. All control variables are lagged by one time period. Statistical significance is denoted at $1 \%(* * *), 5 \%(* *)$ and $10 \%(*)$. 
Table 8: Accounting for firm-level transparency (contd.)

\begin{tabular}{|c|c|c|c|c|c|c|c|c|}
\hline \multirow{3}{*}{$\begin{array}{l}\text { Dependent } \\
\text { variable= }\end{array}$} & $(1)$ & $(2)$ & $(3)$ & $(4)$ & $(5)$ & $(6)$ & $(7)$ & $(8)$ \\
\hline & \multicolumn{4}{|c|}{ Domestic debt/Total debt } & \multicolumn{4}{|c|}{ FX debt/Total debt } \\
\hline & $\begin{array}{l}\text { Foreign } \\
\text { firms }\end{array}$ & $\begin{array}{l}\text { Domestic } \\
\text { firms }\end{array}$ & $\begin{array}{c}\text { Business } \\
\text { group firms }\end{array}$ & $\begin{array}{c}\text { Non- business } \\
\text { group firms }\end{array}$ & $\begin{array}{l}\text { Foreign } \\
\text { firms }\end{array}$ & $\begin{array}{c}\text { Domestic } \\
\text { firms }\end{array}$ & $\begin{array}{c}\text { Business } \\
\text { group } \\
\text { firms }\end{array}$ & $\begin{array}{c}\text { Non- business } \\
\text { group firms }\end{array}$ \\
\hline $\begin{array}{l}\text { Regional } \\
\text { financial cycle }\end{array}$ & $\begin{array}{c}0.051^{* *} \\
(2.25)\end{array}$ & $\begin{array}{c}0.036 * * * \\
(10.55)\end{array}$ & $\begin{array}{c}0.033 * * * \\
(4.79)\end{array}$ & $\begin{array}{c}0.020^{* * *} \\
(6.22)\end{array}$ & $\begin{array}{l}0.020 \\
(0.54)\end{array}$ & $\begin{array}{l}0.012 \\
(1.01)\end{array}$ & $\begin{array}{l}0.017 \\
(0.95)\end{array}$ & $\begin{array}{l}-0.016 \\
(-1.12)\end{array}$ \\
\hline $\begin{array}{l}\text { Global } \\
\text { financial cycle }\end{array}$ & $\begin{array}{l}0.226 \\
(1.24)\end{array}$ & $\begin{array}{l}0.002 \\
(0.07)\end{array}$ & $\begin{array}{l}-0.053 \\
(-1.40)\end{array}$ & $\begin{array}{l}0.048 \\
(1.60)\end{array}$ & $\begin{array}{l}0.653^{*} \\
(1.87)\end{array}$ & $\begin{array}{l}0.163 \\
(1.53)\end{array}$ & $\begin{array}{c}0.285 * * \\
(2.08)\end{array}$ & $\begin{array}{l}0.177 \\
(1.30)\end{array}$ \\
\hline Size & $\begin{array}{l}-0.009 \\
(-0.88)\end{array}$ & $\begin{array}{c}0.010 * * * \\
\quad(6.08)\end{array}$ & $\begin{array}{l}0.001 \\
(0.37)\end{array}$ & $\begin{array}{c}0.011 * * * \\
(6.08)\end{array}$ & $\begin{array}{c}0.066^{* *} \\
(2.28)\end{array}$ & $\begin{array}{c}0.038 * * * \\
\quad(4.14)\end{array}$ & $\begin{array}{l}0.023^{*} \\
(1.71)\end{array}$ & $\begin{array}{c}0.055^{* * *} \\
-5.02)\end{array}$ \\
\hline Liquidity & $\begin{array}{l}-0.003 \\
(-1.42)\end{array}$ & $\begin{array}{c}0.001 * * \\
(1.98)\end{array}$ & $\begin{array}{c}0.002 * * \\
(2.39)\end{array}$ & $\begin{array}{l}0.001 \\
(0.55)\end{array}$ & $\begin{array}{l}0.001 \\
(0.37)\end{array}$ & $\begin{array}{c}0.014 * * * \\
(2.97)\end{array}$ & $\begin{array}{c}0.011 * * * \\
(2.86)\end{array}$ & $\begin{array}{c}0.004 * * \\
(2.19)\end{array}$ \\
\hline Tangibility & $\begin{array}{c}0.190 * * * \\
(3.87)\end{array}$ & $\begin{array}{c}0.077 * * * \\
\quad(5.14)\end{array}$ & $\begin{array}{c}0.103 * * * \\
\quad(6.66)\end{array}$ & $\begin{array}{c}0.068 * * * \\
(3.96)\end{array}$ & $\begin{array}{l}0.030 \\
(0.28)\end{array}$ & $\begin{array}{c}0.096 * * * \\
(3.53)\end{array}$ & $\begin{array}{l}0.063 \\
(1.49)\end{array}$ & $\begin{array}{c}0.090 * * * \\
(2.79)\end{array}$ \\
\hline Export firm & $\begin{array}{l}0.008 \\
(0.49)\end{array}$ & $\begin{array}{c}0.008 * * \\
(2.55)\end{array}$ & $\begin{array}{l}0.004 \\
(0.57)\end{array}$ & $\begin{array}{l}0.010^{* * *} \\
(3.20)\end{array}$ & $\begin{array}{l}0.005 \\
(0.16)\end{array}$ & $\begin{array}{l}0.015 \\
(1.36)\end{array}$ & $\begin{array}{l}0.025 \\
(1.34)\end{array}$ & $\begin{array}{l}0.018 \\
(1.35)\end{array}$ \\
\hline GDP growth & $\begin{array}{l}0.006 \\
(1.48)\end{array}$ & $\begin{array}{c}0.005 * * * \\
(9.64)\end{array}$ & $\begin{array}{c}0.005^{* * *} \\
(6.33)\end{array}$ & $\begin{array}{c}0.006 * * * \\
(9.45)\end{array}$ & $\begin{array}{l}0.011 \\
(1.62)\end{array}$ & $\begin{array}{l}0.002 \\
(0.84)\end{array}$ & $\begin{array}{c}0.008 * * \\
(2.07)\end{array}$ & $\begin{array}{l}-0.002 \\
(-0.75)\end{array}$ \\
\hline Stock returns & $\begin{array}{l}0.011 \\
(0.30)\end{array}$ & $\begin{array}{l}0.010^{*} \\
(1.86)\end{array}$ & $\begin{array}{l}0.016 \\
(1.61)\end{array}$ & $\begin{array}{c}0.018^{* * *} \\
(3.39)\end{array}$ & $\begin{array}{c}0.156^{* *} \\
(2.27)\end{array}$ & $\begin{array}{l}0.010 \\
(0.56)\end{array}$ & $\begin{array}{l}0.038 \\
(0.89)\end{array}$ & $\begin{array}{l}0.006 \\
(0.25)\end{array}$ \\
\hline $\begin{array}{l}\text { Interbank } \\
\text { rate }\end{array}$ & $\begin{array}{c}-0.015^{* * * *} \\
(-2.95)\end{array}$ & $\begin{array}{c}-0.006^{* * * *} \\
(-7.52)\end{array}$ & $\begin{array}{l}-0.003 \\
(-1.48)\end{array}$ & $\begin{array}{c}-0.005^{* * * *} \\
(-5.84)\end{array}$ & $\begin{array}{l}0.006 \\
(0.67)\end{array}$ & $\begin{array}{l}0.001 \\
(0.31)\end{array}$ & $\begin{array}{l}-0.001 \\
(-0.24)\end{array}$ & $\begin{array}{l}0.003 \\
(0.69)\end{array}$ \\
\hline Constant & $\begin{array}{c}0.830 * * * \\
(9.28)\end{array}$ & $\begin{array}{c}0.603 * * * \\
(46.02)\end{array}$ & $\begin{array}{c}0.600^{* * * *} \\
(19.51)\end{array}$ & $\begin{array}{c}0.601 * * * \\
(42.52)\end{array}$ & $\begin{array}{c}1.029 * * * \\
(3.78)\end{array}$ & $\begin{array}{c}0.688 * * * \\
(8.33)\end{array}$ & $\begin{array}{c}0.484 * * * \\
(3.60)\end{array}$ & $\begin{array}{c}0.890 * * * \\
(9.60)\end{array}$ \\
\hline Observations & 4,543 & 168,782 & 34,698 & 134,727 & 638 & 6,321 & 2,560 & 4,400 \\
\hline R-squared & 0.019 & 0.006 & 0.007 & 0.005 & 0.049 & 0.050 & 0.033 & 0.044 \\
\hline Number of firms & 718 & 23,451 & 4,517 & 19,511 & 181 & 1,757 & 609 & 1,328 \\
\hline
\end{tabular}

Notes: The table reports the results of equations (1) and (2). Domestic debt/Total debt is the ratio of proceeds from domestic currency bank borrowings over total debt. FX debt/Total debt is the ratio of proceeds from foreign currency borrowings over total debt. Regional financial cycle is the common factor in bank flows to the countries in the region. Global financial cycle is the common factor in bank flows to all countries in the BIS database. All equations include firm fixed effects. All control variables are lagged by one time period. Statistical significance is denoted at $1 \%(* * *), 5 \%(* *)$ and $10 \%(*)$. 
Table 9: The regional financial cycle and policy responses

\begin{tabular}{lccc}
\hline \multicolumn{1}{c}{ Policy $=$} & $(1)$ & $(2)$ & $(3)$ \\
\hline \multicolumn{1}{c}{ Dependent variable $=$} & \multicolumn{3}{c}{ Domestic debt/Total debt } \\
\hline Regional financial cycle*Policy & $-0.003^{* *}$ & $0.003^{* * *}$ & $0.019^{* * *}$ \\
Regional financial cycle & $(-2.39)$ & $(4.81)$ & $(3.68)$ \\
& $0.017^{* * *}$ & 0.004 & -0.006 \\
Policy (See column) & $(4.68)$ & $(1.58)$ & $(-1.21)$ \\
& $0.002^{* * *}$ & - & $-0.016^{* * *}$ \\
Size & $(6.42)$ & & $(-11.83)$ \\
& $0.006^{* * *}$ & $0.007^{* * *}$ & $0.010^{* * *}$ \\
Liquidity & $(3.87)$ & $(4.28)$ & $(6.50)$ \\
& 0.001 & $0.001 *$ & $0.001 *$ \\
Tangibility & $(1.54)$ & $(1.70)$ & $(1.79)$ \\
& $0.076^{* * *}$ & $0.077^{* * *}$ & $0.078^{* * *}$ \\
Export firm & $(4.90)$ & $(5.17)$ & $(5.24)$ \\
& $0.012^{* * *}$ & $0.010^{* * *}$ & $0.008^{* * *}$ \\
GDP growth & $(4.02)$ & $(3.40)$ & $(2.61)$ \\
& $0.002^{* * *}$ & $0.002^{* * *}$ & $0.005^{* * *}$ \\
Stock returns & $(3.93)$ & $(4.75)$ & $(11.06)$ \\
Interbank rate & $0.020^{* * *}$ & $0.017^{* * *}$ & $0.032^{* * *}$ \\
Constant & $(3.30)$ & $(3.71)$ & $(8.89)$ \\
& $-0.002^{* *}$ & $-0.004^{* * *}$ & $-0.004^{* * *}$ \\
Observations & $(-2.36)$ & $(-4.52)$ & $(-5.40)$ \\
R-squared & $0.618^{* * *}$ & $0.628^{* * *}$ & $0.600^{* * *}$ \\
Number of firms & $(45.97)$ & $(46.23)$ & $(47.31)$ \\
\hline & 161,182 & 168,955 & 173,325 \\
& 0.005 & 0.005 & 0.007 \\
& 23,975 & 23,631 & 24,169 \\
\hline
\end{tabular}

Notes: The table reports the results of equation (3). Domestic debt/Total debt is the ratio of proceeds from domestic currency bank borrowings over total debt. Regional financial cycle is the common factor in bank flows to the countries in the region. Policy indicates macroprudential policy actions, sectoral openness, and exchange rate regime, as indicated in the columns. Macroprudential policy is the annual aggregated MP index by Alam et al. (2019) that is the annual sum of policy actions coded as dummies, +1 for tightening and -1 for loosening actions. Sectoral openness is the maximum share of foreign ownership allowed by regulation in the firms' sectors. Finally, exchange rate regime is the Shambaugh (2004) indicator that is a dummy taking the value of 1 for pegged regimes and 0 for floating regimes. Firm-level controls are: Size as log of total real assets, Liquidity as ratio of quick assets to quick liabilities, Tangibility as ratio of net fixed assets to total real assets, Export firm is a dummy for firms with positive exports, and zero otherwise. Domestic controls are: GDP growth as real GDP growth, Stock returns as returns of the stock market index, Interbank rate as the money market interest rate. All equations include firm fixed effects. All control variables are lagged by one time period. Statistical significance is denoted at $1 \%(* * *), 5 \%(* *)$ and $10 \%(*)$. 
Table 10: China as an emerging lender

\begin{tabular}{|c|c|c|c|c|c|c|}
\hline & (1) & (2) & (3) & (4) & (5) & (6) \\
\hline $\begin{array}{l}\text { Dependent } \\
\text { variable= }\end{array}$ & \multicolumn{3}{|c|}{ Domestic debt/Total debt } & \multicolumn{3}{|c|}{ FX debt/Total debt } \\
\hline Regional factors $=$ & $\begin{array}{c}C H N \\
\text { interbank rate }\end{array}$ & $\begin{array}{c}\text { CHN yield } \\
\text { spread }\end{array}$ & $\begin{array}{c}\text { CHN policy } \\
\text { rate }\end{array}$ & $\begin{array}{c}C H N \\
\text { interbank rate }\end{array}$ & $\begin{array}{l}\text { CHN yield } \\
\text { spread }\end{array}$ & $\begin{array}{c}\text { CHN policy } \\
\text { rate }\end{array}$ \\
\hline Global factors $=$ & $\begin{array}{l}\text { US interbank } \\
\text { rate }\end{array}$ & $\begin{array}{l}\text { US yield } \\
\text { spread }\end{array}$ & $\begin{array}{l}\text { US policy } \\
\text { rate }\end{array}$ & $\begin{array}{l}\text { US interbank } \\
\text { rate }\end{array}$ & $\begin{array}{l}\text { US yield } \\
\text { spread }\end{array}$ & $\begin{array}{l}\text { US policy } \\
\text { rate }\end{array}$ \\
\hline Regional factors & $\begin{array}{c}-0.002 * * * \\
(-3.87)\end{array}$ & $\begin{array}{c}-0.006 * * * \\
(-3.74)\end{array}$ & $\begin{array}{c}-0.002 * * \\
(-2.03)\end{array}$ & $\begin{array}{l}-0.002 \\
(-0.90)\end{array}$ & $\begin{array}{l}-0.007 \\
(-1.12)\end{array}$ & $\begin{array}{l}-0.003 \\
(-0.68)\end{array}$ \\
\hline Global factors & $\begin{array}{c}-0.008 * * * \\
(-11.23)\end{array}$ & $\begin{array}{c}-0.003 * * * \\
(-2.95)\end{array}$ & $\begin{array}{c}-0.005 * * * \\
(-8.36)\end{array}$ & $\begin{array}{c}-0.005^{*} \\
(-1.74)\end{array}$ & $\begin{array}{c}-0.009 * * \\
(-2.05)\end{array}$ & $\begin{array}{c}-0.012 * * \\
(-2.32)\end{array}$ \\
\hline Size & $\begin{array}{c}0.004 * * \\
(2.28)\end{array}$ & $\begin{array}{c}0.002 \\
(1.20)\end{array}$ & $\begin{array}{c}0.008 * * * \\
(5.43)\end{array}$ & $\begin{array}{c}0.045^{* * *} \\
(5.15)\end{array}$ & $\begin{array}{c}0.049 * * * \\
(5.52)\end{array}$ & $\begin{array}{c}0.044 * * * \\
(5.00)\end{array}$ \\
\hline Liquidity & $\begin{array}{l}0.001 * \\
(1.65)\end{array}$ & $\begin{array}{l}0.001 * \\
(1.69)\end{array}$ & $\begin{array}{l}0.001 * \\
(1.82)\end{array}$ & $\begin{array}{c}0.005 * * * \\
(2.86)\end{array}$ & $\begin{array}{c}0.005 * * * \\
(2.86)\end{array}$ & $\begin{array}{c}0.005 * * * \\
(2.86)\end{array}$ \\
\hline Tangibility & $\begin{array}{c}0.068^{* * *} \\
(4.83)\end{array}$ & $\begin{array}{c}0.069 * * * \\
(4.84)\end{array}$ & $\begin{array}{c}0.078 * * * \\
(5.26)\end{array}$ & $\begin{array}{c}0.076 * * * \\
(2.85)\end{array}$ & $\begin{array}{c}0.077 * * * \\
(2.88)\end{array}$ & $\begin{array}{c}0.071 * * * \\
(2.72)\end{array}$ \\
\hline Export firm & $\begin{array}{c}0.007 * * \\
(2.23)\end{array}$ & $\begin{array}{c}0.008 * * * \\
(2.82)\end{array}$ & $\begin{array}{c}0.009 * * * \\
(2.97)\end{array}$ & $\begin{array}{l}0.022^{* *} \\
(1.98)\end{array}$ & $\begin{array}{c}0.024 * * \\
(2.15)\end{array}$ & $\begin{array}{l}0.018 \\
(1.63)\end{array}$ \\
\hline GDP growth & $\begin{array}{c}0.002 * * * \\
(3.88)\end{array}$ & $\begin{array}{c}0.003 * * * \\
(7.15)\end{array}$ & $\begin{array}{c}0.001 * * \\
(2.28)\end{array}$ & $\begin{array}{c}0.007 * * * \\
(3.95)\end{array}$ & $\begin{array}{l}0.002 \\
(1.65)\end{array}$ & $\begin{array}{l}0.002 \\
(1.02)\end{array}$ \\
\hline Stock returns & $\begin{array}{c}0.029 * * * \\
(6.19)\end{array}$ & $\begin{array}{l}0.001 \\
(0.32)\end{array}$ & $\begin{array}{c}0.042 * * * \\
(7.84)\end{array}$ & $\begin{array}{c}0.065 * * * \\
(3.10)\end{array}$ & $\begin{array}{l}0.012 \\
(0.52)\end{array}$ & $\begin{array}{l}0.044 * \\
(1.71)\end{array}$ \\
\hline Interbank rate & $\begin{array}{c}-0.003 * * * \\
(-3.88)\end{array}$ & $\begin{array}{c}-0.004 * * * \\
(-5.84)\end{array}$ & $\begin{array}{c}-0.003 * * * \\
(-3.62)\end{array}$ & $\begin{array}{l}-0.004 \\
(-1.04)\end{array}$ & $\begin{array}{l}0.001 \\
(0.10)\end{array}$ & $\begin{array}{l}-0.002 \\
(-0.59)\end{array}$ \\
\hline Constant & $\begin{array}{c}0.649 * * * \\
(47.97)\end{array}$ & $\begin{array}{c}0.665^{* * *} \\
(51.56)\end{array}$ & $\begin{array}{c}0.616^{* * *} \\
(44.89)\end{array}$ & $\begin{array}{c}0.857 * * * \\
(10.23)\end{array}$ & $\begin{array}{c}0.837 * * * \\
(10.14)\end{array}$ & $\begin{array}{c}0.790 * * * \\
(10.08)\end{array}$ \\
\hline Observations & 163,224 & 163,224 & 173,325 & 6,866 & 6,866 & 6,960 \\
\hline R-squared & 0.004 & 0.003 & 24,169 & 0.040 & 0.040 & 0.037 \\
\hline Number of firms & 23,902 & 23,902 & 0.005 & 1,921 & 1,921 & 1,937 \\
\hline
\end{tabular}

Notes: The table reports the results of equations (1) and (2) with regional and global factors, where regional factors indicate Chinese factors. Domestic debt/Total debt is the ratio of proceeds from domestic currency bank borrowings over total debt. FX debt/Total $d e b t$ is the ratio of proceeds from foreign currency borrowings over total debt. Regional factors are the interbank rates, yield spreads, and policy rate for China (CHN) as indicated in the columns. Global factors are the respective US-based measures. Firmlevel controls are: Size as log of total real assets, Liquidity as ratio of quick assets to quick liabilities, Tangibility as ratio of net fixed assets to total real assets, Export firm is a dummy for firms with positive exports, and zero otherwise. Domestic controls are: GDP growth as real GDP growth, Stock returns as returns of the stock market index, Interbank rate as the money market interest rate. All equations include firm fixed effects. All control variables are lagged by one time period. Statistical significance is denoted at $1 \%(* * *), 5 \%(* *)$ and $10 \%(*)$. 
Table 11: Monetary policy divergence

\begin{tabular}{|c|c|c|}
\hline & (1) & $(2)$ \\
\hline $\begin{array}{l}\text { Dependent } \\
\text { variable= }\end{array}$ & Domestic debt/Total debt & FX debt/Total debt \\
\hline Regional financial cycle*Divergence & $\begin{array}{c}-0.010^{* * *} \\
(-4.03)\end{array}$ & $\begin{array}{l}-0.009 \\
(-0.69)\end{array}$ \\
\hline Regional financial cycle & $\begin{array}{c}0.007^{* *} \\
(2.42)\end{array}$ & $\begin{array}{l}-0.003 \\
(-0.24)\end{array}$ \\
\hline Divergence & $\begin{array}{c}-0.002 * * * \\
(-4.51)\end{array}$ & $\begin{array}{c}-0.008 * * * \\
(-2.66)\end{array}$ \\
\hline Size & $\begin{array}{c}0.009^{* * *} \\
(5.49)\end{array}$ & $\begin{array}{c}0.040^{* * *} \\
(4.60)\end{array}$ \\
\hline Liquidity & $\begin{array}{c}0.001^{*} \\
(1.84)\end{array}$ & $\begin{array}{c}0.005^{* * *} \\
(2.89)\end{array}$ \\
\hline Tangibility & $\begin{array}{c}0.078 * * * \\
(5.28)\end{array}$ & $\begin{array}{c}0.076 * * * \\
(2.88)\end{array}$ \\
\hline Export firm & $\begin{array}{c}0.009 * * * \\
(3.15)\end{array}$ & $\begin{array}{c}0.021^{*} \\
(1.90)\end{array}$ \\
\hline GDP growth & $\begin{array}{c}0.003 * * * \\
(6.04)\end{array}$ & $\begin{array}{c}0.004 * * \\
(1.97)\end{array}$ \\
\hline Stock returns & $\begin{array}{c}0.011^{* *} \\
(2.19)\end{array}$ & $\begin{array}{l}0.037 \\
(1.58)\end{array}$ \\
\hline Interbank rate & $\begin{array}{l}-0.001 \\
(-1.61)\end{array}$ & $\begin{array}{l}0.001 \\
(0.31)\end{array}$ \\
\hline Constant & $\begin{array}{c}0.594 * * * \\
(45.60)\end{array}$ & $\begin{array}{c}0.750^{* * *} \\
(9.30)\end{array}$ \\
\hline Observations & 173,325 & 6,960 \\
\hline R-squared & 0.005 & 0.041 \\
\hline Number of firms & 24,169 & 1,937 \\
\hline
\end{tabular}

Notes: The table reports the results of equations (1) and (2) augmented with the monetary policy divergence between Japan and the US and an interaction term of the regional financial cycle and the monetary policy divergence. Domestic debt/Total debt is the ratio of proceeds from domestic currency bank borrowings over total debt. FX debt/Total debt is the ratio of proceeds from foreign currency borrowings over total debt. Regional financial cycle is the common factor in bank flows to the countries in the region. Divergence is the difference between 3-month Euro-dollar and Euro-yen futures. Firm-level controls are: Size as log of total real assets, Liquidity as ratio of quick assets to quick liabilities, Tangibility as ratio of net fixed assets to total real assets, Export firm is a dummy for firms with positive exports, and zero otherwise. Domestic controls are: GDP growth as real GDP growth, Stock returns as returns of the stock market index, Interbank rate as the money market interest rate. All equations include firm fixed effects. All control variables are lagged by one time period. Statistical significance is denoted at $1 \%(* * *), 5 \%(* *)$ and $10 \%(*)$. 
Table 12: 2SLS regressions

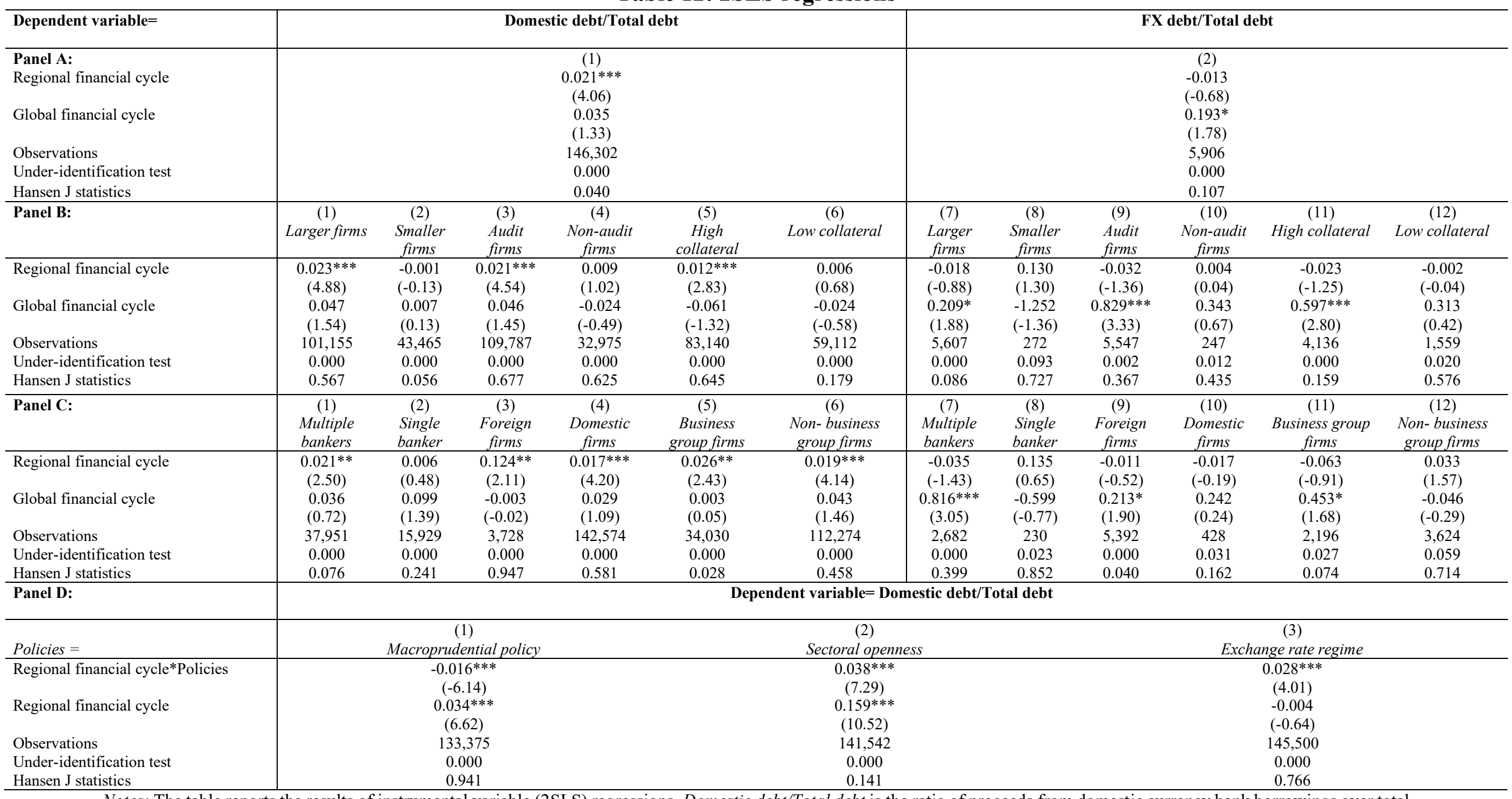

Notes: The table reports the results of instrumental variable (2SLS) regressions. Domestic debt/Total debt is the ratio of proceeds from domestic currency bank borrowings over total debt. FX debt/Total debt is the ratio of proceeds from foreign currency borrowings over total debt. Regional financial cycle is the common factor in bank flows to the countries in the region. All equations include firm fixed effects. All control variables are lagged by one time period. The remaining specifications, which are not reported for brevity, are identical to those in tables $3,7,8$ and 9 . Statistical significance is denoted at $1 \%(* * *), 5 \%(* *)$ and $10 \%(*)$. 


\section{Appendix-}

\section{Table A1: Correlation matrix}

\begin{tabular}{|c|c|c|c|c|c|c|c|c|c|c|c|c|c|c|c|c|c|c|c|c|c|c|c|c|c|c|c|c|c|}
\hline & 1 & 2 & 3 & 4 & 5 & 6 & 7 & 8 & 9 & 10 & 11 & 12 & 13 & 14 & 15 & 16 & 17 & 18 & 19 & 20 & 21 & 22 & 23 & 24 & 25 & 26 & 27 & 28 & 29 \\
\hline 1 & 1.00 & & & & & & & & & & & & & & & & & & & & & & & & & & & & \\
\hline 2 & 0.37 & 1.00 & & & & & & & & & & & & & & & & & & & & & & & & & & & \\
\hline 3 & 0.42 & 0.48 & 1.00 & & & & & & & & & & & & & & & & & & & & & & & & & & \\
\hline 4 & 0.20 & -0.20 & -0.66 & 1.00 & & & & & & & & & & & & & & & & & & & & & & & & & \\
\hline 5 & 0.31 & 0.71 & 0.28 & -0.13 & 1.00 & & & & & & & & & & & & & & & & & & & & & & & & \\
\hline 6 & -0.10 & 0.16 & 0.49 & -0.42 & -0.29 & 1.00 & & & & & & & & & & & & & & & & & & & & & & & \\
\hline 7 & 0.31 & -0.04 & -0.56 & 0.85 & 0.21 & -0.74 & 1.00 & & & & & & & & & & & & & & & & & & & & & & \\
\hline 8 & 0.12 & 0.47 & 0.83 & -0.66 & 0.06 & 0.86 & -0.77 & 1.00 & & & & & & & & & & & & & & & & & & & & & \\
\hline 9 & 0.41 & 0.81 & 0.66 & -0.44 & 0.69 & 0.01 & -0.19 & 0.46 & 1.00 & & & & & & & & & & & & & & & & & & & & \\
\hline 10 & 0.52 & 0.40 & 0.80 & -0.42 & 0.37 & -0.05 & -0.13 & 0.38 & 0.68 & 1.00 & & & & & & & & & & & & & & & & & & & \\
\hline 11 & -0.11 & 0.02 & 0.62 & -0.47 & -0.21 & 0.86 & -0.73 & 0.83 & 0.05 & 0.11 & 1.00 & & & & & & & & & & & & & & & & & & \\
\hline 12 & 0.39 & 0.79 & 0.63 & -0.47 & 0.66 & -0.10 & -0.15 & 0.39 & 0.97 & 0.72 & -0.07 & 1.00 & & & & & & & & & & & & & & & & & \\
\hline 13 & 0.51 & 0.38 & 0.78 & -0.43 & 0.38 & -0.11 & -0.12 & 0.33 & 0.67 & 1.00 & 0.07 & 0.73 & 1.00 & & & & & & & & & & & & & & & & \\
\hline 14 & -0.07 & 0.07 & 0.63 & -0.50 & -0.21 & 0.91 & -0.75 & 0.88 & 0.05 & 0.10 & 0.99 & -0.06 & 0.06 & 1.00 & & & & & & & & & & & & & & & \\
\hline 15 & 0.33 & 0.00 & 0.13 & 0.19 & -0.13 & 0.35 & 0.03 & 0.22 & -0.23 & 0.06 & 0.19 & -0.23 & 0.01 & 0.27 & 1.00 & & & & & & & & & & & & & & \\
\hline 16 & -0.13 & -0.22 & -0.76 & 0.75 & -0.19 & -0.08 & 0.46 & -0.45 & -0.59 & -0.85 & -0.22 & -0.65 & -0.86 & -0.21 & 0.20 & 1.00 & & & & & & & & & & & & & \\
\hline 17 & 0.48 & -0.12 & -0.36 & 0.75 & 0.15 & -0.76 & 0.92 & -0.69 & -0.11 & 0.12 & -0.66 & -0.05 & 0.13 & -0.68 & 0.11 & 0.25 & 1.00 & & & & & & & & & & & & \\
\hline 18 & -0.03 & -0.07 & 0.02 & -0.03 & -0.15 & 0.08 & -0.08 & 0.05 & -0.05 & -0.02 & 0.08 & -0.04 & -0.02 & 0.08 & -0.01 & -0.01 & -0.06 & 1.00 & & & & & & & & & & & \\
\hline $\begin{array}{l}10 \\
19\end{array}$ & 0.01 & 0.00 & -0.00 & 0.00 & 0.01 & -0.01 & 0.01 & -0.01 & 0.00 & 0.00 & -0.01 & 0.00 & 0.00 & -0.01 & 0.01 & -0.00 & 0.01 & -0.09 & 1.00 & & & & & & & & & & \\
\hline 20 & 0.01 & 0.02 & -0.01 & 0.01 & 0.05 & -0.02 & 0.03 & -0.02 & 0.02 & 0.00 & -0.02 & 0.01 & 0.00 & -0.02 & 0.01 & 0.01 & 0.02 & -0.00 & -0.12 & 1.00 & & & & & & & & & \\
\hline 21 & -0.02 & 0.00 & -0.02 & 0.01 & 0.02 & -0.02 & 0.02 & -0.02 & 0.00 & -0.00 & -0.02 & 0.01 & -0.00 & -0.02 & 0.00 & 0.00 & 0.02 & 0.29 & -0.07 & 0.00 & 1.00 & & & & & & & & \\
\hline $\begin{array}{l}21 \\
22\end{array}$ & -0.05 & 0.45 & 0.25 & -0.14 & 0.22 & 0.42 & -0.15 & 0.39 & 0.24 & 0.19 & 0.15 & 0.21 & 0.13 & 0.23 & 0.41 & -0.17 & -0.22 & -0.06 & 0.01 & 0.02 & 0.03 & 1.00 & & & & & & & \\
\hline 23 & 0.36 & 0.66 & 0.67 & -0.17 & 0.56 & 0.34 & -0.12 & 0.59 & 0.67 & 0.56 & 0.40 & 0.56 & 0.51 & 0.41 & 0.28 & -0.34 & -0.05 & -0.06 & 0.00 & 0.02 & 0.01 & 0.59 & 1.00 & & & & & & \\
\hline 24 & -0.09 & -0.27 & -0.04 & -0.08 & -0.39 & 0.15 & -0.28 & 0.13 & 0.01 & -0.23 & 0.21 & -0.05 & -0.23 & 0.19 & -0.23 & 0.06 & -0.14 & 0.10 & -0.02 & -0.03 & -0.01 & -0.32 & -0.10 & 1.00 & & & & & \\
\hline 25 & 0.47 & 0.67 & 0.39 & 0.17 & 0.34 & 0.20 & 0.23 & 0.33 & 0.35 & 0.45 & 0.06 & 0.37 & 0.39 & 0.11 & 0.42 & -0.11 & 0.20 & -0.03 & 0.01 & 0.01 & -0.00 & 0.51 & 0.63 & -0.50 & 1.00 & & & & \\
\hline 26 & -0.01 & -0.01 & 0.01 & -0.01 & -0.03 & 0.02 & -0.03 & 0.02 & -0.00 & 0.00 & 0.02 & -0.00 & -0.00 & 0.02 & -0.01 & -0.01 & -0.02 & 0.07 & -0.17 & 0.10 & 0.14 & -0.01 & -0.01 & 0.02 & -0.00 & 1.00 & & & \\
\hline 27 & -0.34 & 0.04 & 0.26 & -0.23 & -0.20 & 0.35 & -0.38 & 0.40 & 0.02 & 0.10 & 0.46 & 0.06 & 0.09 & 0.45 & 0.22 & -0.11 & -0.28 & 0.06 & -0.01 & -0.02 & 0.03 & 0.26 & 0.23 & 0.14 & 0.02 & 0.02 & 1.00 & & \\
\hline 28 & $\begin{array}{l}-0.04 \\
-0.44\end{array}$ & $\begin{array}{l}0.04 \\
0.08\end{array}$ & $\begin{array}{l}0.20 \\
0.38\end{array}$ & -0.65 & $\begin{array}{l}-0.20 \\
-0.27\end{array}$ & 0.34 & $\begin{array}{l}-0.30 \\
-0.58\end{array}$ & $\begin{array}{l}0.40 \\
0.47\end{array}$ & $\begin{array}{l}0.02 \\
0.13\end{array}$ & $\begin{array}{l}0.10 \\
0.31\end{array}$ & $\begin{array}{l}0.40 \\
0.35\end{array}$ & $\begin{array}{l}0.00 \\
0.26\end{array}$ & $\begin{array}{l}0.09 \\
0.31\end{array}$ & $\begin{array}{l}0.45 \\
0.37\end{array}$ & -0.13 & -0.58 & -0.52 & 0.10 & -0.01 & -0.04 & -0.00 & 0.16 & 0.00 & 0.01 & 0.09 & 0.03 & 0.54 & 1.00 & \\
\hline 29 & 0.09 & -0.32 & -0.16 & -0.11 & -0.29 & -0.28 & 0.10 & -0.27 & -0.29 & 0.08 & -0.42 & -0.08 & 0.11 & -0.34 & 0.13 & -0.18 & 0.22 & 0.02 & -0.00 & -0.01 & 0.00 & -0.13 & -0.56 & -0.04 & -0.19 & -0.00 & -0.09 & 0.22 & 1.00 \\
\hline
\end{tabular}

Notes: The table presents the correlation matrix between all explanatory variables: (1) Regional financial cycle; (2) Global financial cycle; (3) Regional interbank rate; (4) Regional yield spread; (5) Regional policy rate; (6) US interbank rate; (7) US yield spread; (8) US policy rate; (9) JP interbank rate; (10) AUS interbank rate; (11) SG interbank rate; (12) JP policy rate; (13) AUS policy rate; (14) SG policy rate; (15) JP yield spread; (16) AUS yield spread; (17) SG yield spread; (18) Size; (19) Liquidity; (20) Tangibility; (21) Export firm; (22) GDP growth; (23) Stock returns; (24) Interbank rate; (25) Macroprudential policy; (26) Sectoral openness; (27) Exchange rate regime; (28) US monetary policy uncertainty; (29) JP monetary policy uncertainty. 


\section{Table A2: Impact of regional factors on regional financial cycle}

(1)

Regional financial cycle

\begin{tabular}{lc} 
& Regional financial cycle \\
\hline & \\
Regional interbank rate & $-0.422^{* *}$ \\
& $(-2.26)$ \\
Regional yield spread & $-0.064^{* *}$ \\
& $(-2.53)$ \\
Regional policy rate & 0.049 \\
& $(0.93)$ \\
Constant & -0.176 \\
& $(-1.34)$ \\
Observations & 19 \\
R-squared & 0.347 \\
\hline
\end{tabular}

Notes: The table presents the results of a regression of the regional financial cycle on a series of regional factors, including regional interbank rate, regional yield spread and regional policy rate, and a constant. $T$-stats are reported below the coefficients. 